\title{
3
}

\section{Historicizing Pindar:}

\author{
Pythian 10
}

I hope to convince you that it is precisely the path through the aesthetic question that we are obliged to take in any ultimate solution of the political question, for it is through beauty that we arrive at freedom.

—Friedrich Schiller

Letters on the Aesthetic Education of Man

If the task of any Marxist criticism worthy of the name is to historicize the text, the challenge is peculiarly acute in the case of Pindar-the first major author after Hesiod to survive in sufficiently complete texts to permit a serious encounter with a politics of form. The problem has several dimensions, which I separate for purposes of analysis. First is the traditional perception of Pindar's place in the unfolding of any putative historical continuum between Homer and the fifth century. One needs both to assess the political and social developments of this period and reassess the characteristic ways Pindar is situated in relation to them. Second, we need to evaluate the ways Pindar has until quite recently been historicized within the fifth-century context. Here the apparent explicitness of Pindar's political allegiances, at least in the eyes of those who acknowledge the presence of a significant political dimension in the text of his surviving odes, has confronted many readers with a sense that they must take a stand against Pindar or find a way indirectly to endorse his vision. In this connection, the very perception of Pindar's immersion in the politics of his time has of ten led to a peculiarly troubled treatment of the chronology of the poems. Third, there is the powerful attempt characteristic of most recent Pindaric scholarship to save Pindar's reputation as a poet by defining his poetic activity and production in radically apolitical terms. As indicated, I attempt to explore and respond to these aspects of what might be called "the Pindaric problem" separately, but it is essential to keep in mind that they arise as problems because of the ambiguity of the notion of historicization. Finally, in the course of historicizing the 
new formalism in contemporary Pindaric criticism, I offer a general assessment of the relation of his deployment of the epinician form before venturing a reading of what is generally accepted as Pindar's first datable epinician, Pythian 10.

\section{Pindar's Place in the So-Called Lyric Age}

Pindar is almost invariably treated as the tail-end figure-sometimes in conjunction with Bacchylides-of a temporal span beginning with Archilochos, the first known literary figure after Hesiod and Homer. ${ }^{1}$ Pindar thus emerges as unambiguously backward-looking and irretrievably archaic in several senses of the word rather than as a figure fully enmeshed in the intellectual, social, artistic, and political developments of the first half of the fifth century. This approach follows from legitimate grounds; but, as I try to show, it involves some distinct distortions.

Since one of our chief interests in this study is the politics of form, it is worth noting that Pindar emerges as virtually the first literary figure after Homer whose artistic output comes to us in a group of poems primarily conf ined to a recognizable genre-poems that in most cases are formally indisputably complete. ${ }^{2}$ This is not to deny that there may well be complete poems among the fragments of earlier lyric and elegy, but not only does the haphazard transmission of those texts make one wary, the very forms of the remains between Archilochos and Pindar seem in varying degrees indifferent to considerations of completeness. Elegy is the most obvious example. ${ }^{3}$ One of ten feels a sense of the com-

\footnotetext{
'Murray's condensed overview is quite typical of more elaborate discussions: "The earliest, ... Archilochos. . . Finally, the greatest of the choral lyric poets, Pindar" (1980: 24-25). It is striking that Murray's actual citations of Pindar (195-208) almost all fall after his own chosen terminus, the Persian wars. Among older treatments, Fränkel 1973 is perhaps canonical; its final chapter, "The Last of Archaic Lyric," begins its discussion of Pindar with the following sentiment: "As the most characteristic and highly-bred product of the epoch it [choral lyric] did not attain its finest development until the epoch itself was near its climax and decline. Thus the archaic age of Greek literature found its ultimate crown of poetry in the choral odes of Pindar. ... Pindar remained untouched by the revolution in ideas that was going on around him" (425-2-6, emphasis added). Note also the title of Davison's collected papers, From Archilochus to Pindar (1968). So too Podlecki, despite the "early" in his title, concludes with a chapter on Pindar and Bacchylides (1984: 203-50). Fowler, who also has an "early" prominent in his title, ends his discussion of genres with the epinician (1987: 100-101) where we might have expected a discussion of the alleged origins in Simonides. But, in fact, his brief discussion centers entirely on issues raised by Bundy about Pindar's handling of the genre.

${ }^{2}$ This comment implies no conclusions about the largely lost corpus of Pindar's work and the forms in which these were gathered, on which see Race 1987.

3See Fowler's conclusion: "We are forced to conclude that elegy was not an archaic genre, in any identifiable sense of the word. Is it then a group of genres? It might be possible to divide the corpus according to the various occasions" $(1987: 102)$. Although
} 
pleteness of a particular combination of lines in Solon or Theognis, but the possibility of this sense being purely subjective is quite great. The situation is more precarious and inherently speculative in the case of the fragments of monody and choral lyric. Thus, whereas we can reasonably trace all sorts of significant developments and trends in the remains of the so-called lyric age, we would be at a loss to go very far in exploring any particular configuration of lines as the realization of a specific politics of form.

We must return to the issue of the origins and nature of the epinician form in its historical context, but first it is essential to offer a necessarily somewhat schematic overview of the most important historical developments to which historicizing reading must present Pindar's poetry as in some sense a response. The equivocation is essential because of the task we have set ourselves of avoiding a simple reflectionism: fused with the "reflection" of developments is a creative, constructive response to a perceived set of problems, of threats, and of limited options.

Historical analysis of a period of complex change obviously does not yield unambiguous results, and the distinction between what might be called a crisis and simply a successful adaptation of a social system to significant changes is by no means always clear (Habermas 1975: $3^{-8}$ ). My own tentative assessment is that the whole Archaic period should be seen as an era of ever-deepening crisis which culminates in the full crisis, or crisis proper, with the emergence of a successful democratic Athens and the concomitant elaboration of sophistic discourse. But here I only glance at some of the successive phases. By their nature, these are simultaneously at the level of both institutional and discursive shifts.

In the Iliad we traced the opposition within the ruling elite between a view of birth as a metaphoric image of absolute superiority and as a mechanism for transmitting wealth and power not necessarily linked with excellence. The issue is fought out within the ruling elite on the terrain of who shall be king. In the Odyssey this split takes on a more concrete character of interclass conflict to the extent that, behind the facade of atemporal heroics, the suitors reflect the aspirations of eighth-century oligarchy, and Odysseus evokes indirectly both the suppressed resentments of the peasants and the aspirations of the colonizing element. Within the corpus of works attributed to Hesiod we saw a parallel ambiguity between explicit peasant-class resentment directed

Fowler in fact regularly operates on the assumption that there are complete poems in the corpus, criteria of completeness is not an issue he deals with. Figueira $\left(198_{5}: 135,139\right)$ argues that elegy in Megara was de facto an aristocratic genre to indoctrinate the young, but his formulation is too narrow to generalize about all Archaic elegy, and it comes perilously close to a tautology based on the content of Theognis. 
at the oligarchs (most notably in the Erga) and a major contribution to the ideology of the elite in the elaborations of heroic genealogy in the Eoiai.

Between Hesiod and Pindar we must look at least summarily at those developments that most decisively affected the terms in which the foundational ideological construct of the Greek aristocracy-the belief that excellence of every meaningful sort is transmitted by birth-are fought over. The conditions of possibility for sustaining such a belief are constituted by the new alternatives that emerged in this period and the threats these alternatives posed. Thus, if in the Iliad many readers have been able to perceive only a univocal aristocratic message (for a contrary view see Rose 1988), with Hesiod and those who follow him the apparent aristocratic monopoly of discourse is unequivocally shattered. Peasants, colonists, men of mixed lineage on the margins of the aristocratic charmed circle, hoplites, traders, tyrants, women, dissenting and of ten uprooted intellectuals- "philosophers"-all in varying degrees enter the discursive arena. All constituted in varying degrees a potential threat to the aristocratic vision of reality. ${ }^{4}$ If Pindar often gives modern readers the impression that he speaks from and to a homogeneous and untroubled aristocratic world, that is in part at least the mark of his triumph as a professional ideologue.

At the same time, it is one of the chief paradoxes one senses in reading over various histories of this period that, although the major space is understandably devoted to spelling out the emergence of all the new forces challenging the aristocracy, it is usually acknowledged that by and large "throughout the period, despite the existence of a selfconscious hoplite class, political leadership (as distinct from political power) was still in the hands of the aristocracy" (Murray 1980: 193). The aristocracy's success is due in no small measure to its capacity to engage effectively in ideological warfare on a whole spectrum of cultural fronts.

In discussing the colonizing and trading element in the Odyssey, we noted in passing the ambiguous posture of the aristocracy. On the one hand, we noted a self-conscious, class-based scorn of traders suggestively grounded in purely athletic prowess (see $\mathrm{Od} .8 .159-64) .{ }^{5}$ On the other, we saw in the stridency with which the poem insists on the protagonist's legitimate claims to full aristocratic status a reflection of the

\footnotetext{
${ }^{4} \mathrm{~A}$ good recent overview of these developments is Murray 1980 ; Murray has a keen appreciation of the potential for overlaps between these categories.

${ }^{5} \mathrm{D}$. C. Young's failure to discuss this passage $(1985)$ attests to his curious indifference to issues of ideology. But someone who describes the modern Olympic movement as "potentially, perhaps, [the world's] greatest hope" (ix) is-whatever his other accomplishments-not a serious political thinker.
} 
fact that, for the colonizing element in Greek society, the attraction of colonization was to acquire the economic land base essential for realizing their own aspirations to an aristocratic lifestyle. This duality seems symptomatic of later developments. Trade and colonization constituted threats to the aristocracy to the extent that they created new wealth for non-aristocrats and exposed Greek society as a whole to a range of social and political alternatives that threatened to undermine the sense of the naturalness of the status quo that was its best defense. Thus, for example, Aristotle cites the poet Simonides' declaration that the "well-born" are simply "those whose family has long been rich" (Barnes 1984: $2422=$ F92 R). The reforms of Solon in Athens constitutionally confirmed the supplanting of birth by wealth (Murray 1980: $185-87$ ) in the designation of class, which seems to be characteristic of this period in Greece as a whole.

The aristocracy maintained down to Plato and Aristotle an official, so to speak, scorn of traders and all other nations or "races." Wealth as a criterion of worth was of ten bitterly denounced. The aristocrat Alkaios expresses the resentment of his class by citing a Spartan sage:

For indeed once upon a time they say

Aristodamos spoke in Sparta a speech

Not devoid of value: "Wealth is the man,

But the poor man's neither noble nor honored."

Theognis is more explicit in denouncing the disruptive potential of wealth:

Kyrnos, when it comes to goats, asses and horses, we seek

Well-born ones [eugeneas], and one wants them to come from

Good ones [agathōn]; but in marriage a noble man [esthlos] doesn't grieve at

Marrying a base daughter [kakēn] of a base father [kakou], if she gives him lots of wealth,

Nor does a woman refuse to be the bed-partner of a base [kakou] husband,

If he's rich; but she prefers wealth to a noble [agathou].

They honor wealth: the noble [esthlos] marries a base man's [kakou] daughter

And a base man [kakos] marries a noble's [agathou]: wealth has mixed up lineage [genos].

${ }^{6}$ Poetaram Lesbiorum Fragmenta $\mathrm{Z}$ 37. Page cites this fragment among "The Non-Political Poems" and is at pains in his notes to deny that it is relevant evidence "for the 'struggle between a class of impoverished aristocrats and parvenu merchant-princes' of which we hear so much in modern accounts of Lesbos at that era" (1959: 31 $\left.5^{-16}\right)$. 
So don't marvel, son of Polypais, that the lineage [genos] of the citizens

Is being weakened: for what's noble [esthla] is mixed with what's base [kakois].

(M. L. West $183-92)$

In reality, the mixing and social confusion Theognis laments appears to have worked both ways. As Hesiod, Solon, and others abundantly attest, the aristocrats were in fact second to none in their devotion to gain of all kinds. The aristocracy usually supplied leadership to new colonies, where the newly landed peasants aspired to become and not infrequently did become a new aristocracy, sharply distinguished in class from later arrivals who had not benefited from the initial distribution of land (Murray 1980: 111 ). Moreover, the aristocracy was sufficiently flexible to graft the most successful of the merchant class onto its own ideological family tree. Thus, for example, the ruling elite of the little rocky island of Aegina could not possibly owe its great wealth to agricultural land. On the contrary, there is considerable evidence for viewing commerce as the chief economic activity of Aegina (Murray 1980: $211-13) .{ }^{7}$ Yet Pindar is at pains to represent Aegina's ruling families as the supreme embodiment of the principle of inherited excellence.

We saw in the Odyssey's celebration of the monarchic principle not just a nostalgic backward look at the long lost world of the Mycenaean wanax but a utopian anticipation of the return of one-man rule in the wave of tyrants that swept over Greece in the period from the mid-seventh century down to the period of the Persian wars. Characteristically, this new political form arose in violent opposition to entrenched, narrow aristocracies and with the military support of independent peasants wealthy enough to buy a set of armor ( $t a$ hopla) and fight in the new, more cooperative phalanx as hoplites. ${ }^{8}$ Whether

${ }^{7}$ Ste. Croix $(1972 ; 1981: 41)$ is quite emphatic in his denial of this point apropos of Aegina. But pending the appearance of his promised detailed discussion, I am inclined by my own recollection of the rocky harshness of the terrain to be highly skeptical that it could support even a "small, rich, landowning class of archaic type" (1972: 267 n. 61). I also find persuasive Murray's allusion to the frequency of shipping imagery in Pindar's Aeginetan odes-especially in the light of Aegina's clearly extensive trade (Herodotus $2.178 .3,4.152 .3,7.147 .2$ ), exceptional wealth (Herodotus $5.81 .2,9.80 .3$ ), and extraordinary naval power (Herodotus 3.59.3, 5.83-89, 8.46.1, 8.93.1), with How and Wells's commentary 1961 [1912], ad loc.). Ste. Croix seems to me here to be going too far in exorcising the much ridiculed older Marxist explanation of all changes in terms of an alleged "rising middle-class of merchants"-a theory much in evidence, for example, in Cornford's Thucydides Mythistoricus (1965 [1907]).

${ }^{8}$ On tyrants and hoplites, see, in addition to Murray 1980: chaps. 8-10, the suggestive juxtaposition of Cartledge 1977 and Salmon 1977. In the course of denying "political hoplites," Salmon concedes so many grounds for anti-aristocratic sentiment among those who became hoplites that his argument boils down to a denial of a pure technologism (i.e., that the military innovation per se created revolutions) and a quite unobjectionable 
these wealthier peasants expressed only their personal aspirations for power or acted in solidarity with the most oppressed peasants is perhaps impossible to say for the entire range of revolutions in the Archaic period. We can infer, I believe, from the Athenian evidence in the period of Solon, that his "middle" course reflected the ambivalence of the hoplite element: they opposed debt-slavery and bitterly denounced the greed of the so-called Eupatrids, but they drew the line at a redistribution of the land-their own basis for power.

In any case, the new cooperative style of warfare confirmed the military irrelevance of the old individualist style celebrated in Homer and on which the aristocratic claim of an equation between merit and birth depended. The old military aristocracy became an aristocracy of leisure. Yet the institutionalization of their chief leisure activities-games and drinking parties (symposia)—dominated the cultural imagination of both the tyrants, who in any case usually came from and shared the values of the aristocracy, and the new hoplite class. Though alternatives were occasionally articulated, the aristocracy generally succeeded in sustaining its cultural hegemony. But here again it is always important to stress that their hegemony is a consequence of a struggle in arenas that were significantly open to challenge from lower orders.

A vaguely populist case has recently been made with great vigor against the widespread and unfounded notion that only aristocrats participated in the games during the Archaic and Classical periods (D. C. Young 1985). What needs to be historicized, however, are the circumstances and the politics implicit in the institutionalization of, in the commitment of substantial public funds to, athletic contests during the period when the aristocracy had political dominance but was subject to the array of challenges we have described. ${ }^{9}$ To invoke simply the

def ense of the operation of multiple causes. I find Cartledge's more explicitly political analysis quite eloquent and compelling (his documentation is particularly rich). The attack on the "hoplite theory" mounted by Sealey $(1976: 39-59)$ is by contrast aimed only at the crudest version of a technologist account and offers nothing but disiecta data and arbitrary speculation about peasant emotional needs in place of a coherent construction of complex phenomena.

${ }^{9}$ The circumstances under which the Olympic games were formally organized are completely shrouded in myth, though Strabo's view that the newly arrived Dorians (the "Herakleidai") organized them and the tradition that the Spartan king Lykourgos was somehow involved are suggestive (Yalouris 1979: 82). We know that the Pythian contest was organized by a Thessalian commander, Eurylochos, sufficiently rich himself to win a prize in the new chariot races at Olympia (Jeffery 1976: 74). As for the Isthmian games, Jeffery suggests, "possibly these were established by the oligarchic families to celebrate the return of constitutional government" (i.e., after the tyrant Psammetichos, son of Kypselos, had been deposed) $\left(1976: 15^{2}\right)$. She has a more complex suggestion for the sixth-century organization of the Nemean games (137) but again sees them arising in opposition to a tyrant in a period when the only practical alternative to tyranny was oligarchy. 
Greek's nature (D. C. Young 1985: 175) finesses the historical and political issue. To be sure, there were bound to be members of a middle class (D. C. Young $1985: 158)$ who has sufficient talent to achieve not only athletic success but the political stature that so of ten accompanied it. Young also most appropriately stresses the material rewards $\left(115^{-}\right.$ 27) that made a career in sports extremely attractive to all Greek males. But because it was a "symbolic test of the individual man" where "there were no trappings of birth or rank" and "on the track, noble and nonnoble necessarily looked alike" (175-76), the structural advantages of the aristocracy-leisure, wealth, family traditions-weighted this site of struggle more clearly to their advantage than the battlefield of hoplites in lockstep. ${ }^{10}$

But if for the sake of analysis we separate purely linguistic practice from all the social, economic, and political institutions in which it is imbedded, the clearest and deepest threats to aristocratic ideological hegemony would seem to us to come from the heterogeneous group of intellectuals usually lumped together under the title of "Presocratic philosophers"-two terms that peculiarly represent the triumph of a current of thought largely hostile to much of these thinkers' intellectual output. Plato, who, as we shall see, had a deeply partisan attachment to traditional aristocratic culture, succeeded in imposing both his master Sokrates as the watershed figure of Greek thought and his preferred term philosophos (lover of wisdom) over the earlier and once non-prejorative designation sophistēs (wiseman). Xenophanes, one of these wisemen, directly challenges one of the two major institutional foundations of aristocratic class consciousness, the great games. In one poem he declares boldly, categorically, that "better than the strength of men or of horses is our sophia" ( $D-K$ B 2.11-12). The term sophia here has moved from its Homeric sense of the skill of any craftsman to evoke the fruits of the intellectual's skills, which Xenophanes goes on to specify as primarily relevant to the goal of bringing the city into $e u$ nomia ( $D-K \mathrm{~B} 2.19$ ), a term that during this period had come to designate whatever sort of good order proved necessary to end the threat of open class warfare. ${ }^{11}$

The second major ideological institution of the aristocracy in the Archaic period, the symposium, is not attacked directly by Xenophanes; rather, in another poem he seeks to purge both its form and its con-

\footnotetext{
${ }^{10}$ The fact that Tyrtaios, the ultimate "hoplite poet," begins his sustained priamel in praise of hoplite prowess with a dismissal of that "aretē of feet or wrestling" (12.1-2 West) suggests how early this agonistic individualism entered the discursive ranks against a specif ically "communal good" (ksunon esthlon, 12.15 West).

"For the essential continuity between Xenophanes' eunomie and Solon's, see Ostwald 1969: 69-70.
} 
tent. He wants no outrageous violence (hubris, $D-K$ B 1.17) and no drinking to excess. Poetry, which constituted the most ideologically self-conscious dimension of the symposium, should-according to Xenophanes-consist of praise of god (theon, sing., $D-K \mathrm{~B} 1.13$ ), prayer for the ability to act justly (ta dikaia dynasthai prēssein, $D-K \mathrm{~B} 1.15^{-16}$ ), and accounts (narratives?) in which concern for excellence (aretē, $D-K$ B 1.20) is uppermost. ${ }^{12}$ But the battles of titans, giants, or centaurs are strictly forbidden subject matter. This last injunction, combined with the singular theon, points toward the categorical repudiation of anthropomorphic religion which Xenophanes spells out in other poems. This attack seems to be inseparable from Xenophanes' rejection of Homer and Hesiod as bad teachers who have offered scandalously immoral accounts of divine behavior $(D-K \mathrm{~B} 10,11,12)$. It is a moot point perhaps how far traditional Archaic aristocrats were committed to a literal belief in the religion implicit in the texts of Homer and Hesiod. But some political consequences of undermining this religion are clear: if one were to reject completely the anthropomorphic narratives of the gods' sexual encounters with mortals, it would knock out a major metaphysical prop of the aristocrats' claims to be a race apart from mere mortals. In Xenophanes' terms, they would be no different from all other creatures that are born and grow; for "all are earth and water" ( $D-K$ B 29).

Xenophanes, to be sure, had his own particular configurations of ideas, but the thrust of all the speculations of the so-called physikoi together with Pythagoreans, Eleatics, atomists, or any other school of serious thinkers during this period was radically at odds with the old mythology and all the glorious, divine origins imbedded in its genealogies. In particular, whether the physikoi actually used such terms as Peri Phuseos ("About Nature") to describe their speculations (HGP 1:73), the whole direction of their analyses of natural phenomena was to reduce severely the spheres and scope of unexpected and at least in appearance arbitrary divine intervention. ${ }^{13}$ The very word phusis and its variant form phue (Doric phua) mark in their development during this period the trajectory from a severely circumscribed realm of the natural to the dominant force of Nature. In Homer, where phusis occurs but once and phue is used nine times in a corpus of 27,00o lines, the noun seems closely linked with the verb phū, "to grow or grow into

\footnotetext{
${ }^{12}$ Gerber 1970 and Campbell ${ }_{1967}$ both express hesitation over the text of line 20 and in particular the meaning of tonos, an emendation based on the analogy to Pindar Py. 11.54 .

${ }^{13}$ In discussing the history of phusis and associated words, I am indebted, in addition to Guthrie's scattered comments, to Heinimann 1965 (1945), Haedicke 1936, Pohlenz 1953 , Beardslee 1918 , and Thimme 1935 . The fascination of this topic to Germans during the Nazi period is striking, and it would be quite easy to expand considerably this list with German names.
} 
something." Thus both forms seem to designate the physical, visible consequence of the growth process: phusis designates the appearance, the visible form of the plant that Hermes gives Odysseus to protect him from the magic of Kirkè (Od. 10.303), while phue, almost always in the form of the accusative of respect and frequently combined with eidos (the "form," or simply "looks" in the modern colloquial sense) and demas ("living body" or "stature"), indicates the specifically human form or appearance-"build" or physical "presence" in the sense of impressive appearance.

However much the details are obscured by the fragmentary character of the direct archaic evidence, it does seem legitimate to deduce from the apparent continuities of this evidence with abundant fifthcentury data that the Presocratics dramatically extended the spheres of the regularity associated with the consequences of the growth process. It may seem a short step from Homeric phusis as the actual consequences of the growth process to the sense we first have attested in Herakleitos but presumably characteristic of all the Milesians, namely, the true being or essence of a thing-its nature $(D-K \mathrm{~B} 1,123)$. But in this sense it is opposed to mere appearances and takes on the connotation of genuineness, of authenticity. What is radical in this shift and in the new prominence given to the word is the "substitution of natural for mythological causes, that is, of internal development for external compulsion" (Guthrie, HGP 1:83, echoing Pohlenz 1953). In Herodotus and in the medical writers of the fifth century phusis comes then to mean the normal condition as opposed to a sick or fortuitous state of people or things. Specifically applied to individual human beings or to the generality of human individuals, the term came to designate the particular, essential character of individuals, or human nature in general (HGP 2:351-53).

Can we trace a specifically aristocratic response to these developments in the conception of the specifically human? We noted that the Iliad was, in comparison with later developments, relatively indifferent to lineage and in fact distinctly ironic in its handling of the motif of descent from divinity. Homer has little or no vocabulary celebrating a specifically inherited excellence. The Odyssey shows a significantly greater self-consciousness about both the ruling-class look and the origin of human dynasties in divine rapes. But it is during the Archaic period proper that the discursive counterattack of the aristocracy emerges. On the one hand, heroic myth is relentlessly reinforced in major public festivals and vase painting. ${ }^{14}$ On the other, a whole vo-

\footnotetext{
${ }^{14}$ On the cultural policies of Solon and Peisistratos, see in particular Else $(1965: 46-$ $5^{\circ}$ ), who notes in passing the relative absence of heroic themes on vases before c. $5^{80}$ B.C.
} 
cabulary equating human excellence with aristocratic birth is valorized and elaborated. Homer has but one instance of gennaios, probably meaning something like "appropriate or worthy of one's family" (genos); and Helen, daughter of Zeus, is once referred to as eupatereia, "child of a good father." But in the Archaic period the whole Athenian aristocracy described itself as the Eupatridai, literally, "sons of good fathers" (Calhoun 1934a: 197). One of the subtler forms of this linguistic strategy, clear in the passage from Theognis quoted above, is to transform the strongest terms of approbation precisely into terms implying specifically aristocratic birth. Thus the adjectives (and their prefix forms) kalos ("fine looking") or eüs ("good") or agathos (also "good") and kakos ("bad") come inevitably to mean respectively "nobly born" and "base-born."

\section{The Problem of Pindar's Politics}

We treat in more detail Pindar's relation to the discursive counterassault by the aristocracy in connection with his use of the epinician form later in this chapter. But for those aware of this development throughout the Archaic age, Pindar's special contribution-his valorization of inherited excellence under the banner of phua-has been a decisive factor in the widespread apprehension that Pindar is among the most blatantly political Greek poets in a tradition in which politics in most senses of the word had rarely been absent. ${ }^{15}$ On this level, Pindar's poetry has conf ronted many modern readers with the fascinating problem of an art they find deeply engaging but which is, to all appearances, clearly committed to a strikingly reactionary political perspective-even in the context of its own era. A look at Pindaric scholarship suggests a more general problem, one relevant in varying degrees to the study of virtually all classical authors.

As Moses Finley asks in his review of Bowra's Pindar, "can one divorce a great poet from his deeply felt but odious beliefs?" (1968: 41). To Finley the answer seems clear. After literally pro forma praise for "structures ... carefully worked" and "technical skill of the highest order" (39), Finley observes: "It is hard on occasion to resist the word 'toady', but Sir Maurice, too kind and excusing, manages to do so" (40). He concludes: "From Pindar we get neither understanding nor even

Although the precise dating of the Homeric hymns remains problematic, most are generally assumed to be from the Archaic period and associated with the various festivals inaugurated during that period.

${ }^{15}$ E.g., Heinimann 1965: 99-101, Thimme 1935: 18-24, Haedicke 1936: 50-56, and Beardslee 1918: 6-7. 
clear awareness that new impulses are in the air for him to resist" (43). Finley's position with respect to Pindar's politics is not so far from that of Norwood, who devoted a witty chapter to demonstrating that Pindar's views on religion, ethics, sociology, and politics are "a tangle of contradictions and prejudices" (1956: 44). He exclaims in final exasperation: "Who shall discern limits to the lethal stupidity of a longdormant class whose education has been moulded to suit, not to correct their prejudices?" $(67)$. Unlike Finley, Norwood took formal structures and technical skill seriously. He concentrated on stylistic aspects as inherently so admirable and exciting that one could ultimately ignore the content of the poems. In this respect at least-even if his peculiar conception of symbolism has not found favor-he anticipated the dominant thrust of Bundy's (1962) and post-Bundian Pindaric scholarship, which we must consider in due course.

\section{Pindaric Chronology}

The conviction of most pre-Bundian Pindaric scholarship that Pindar is so clearly a political poet profoundly affected their relation to the always sensitive problem of the chronology of the poet's works. It is essential, I think, to stress that these scholars' assumptions about Pindar's form-the epinician genre-dictated the stance they took toward issues of chronology. This assumption was stated as well by Croiset as by anyone: "An ode of Pindar's is not a work of pure imagination created arbitrarily by the enthusiasm of a dreamer; it is in direct and compelled (forcée) relation with the circumstances in the midst of which it is produced" (1880: 305). Given this assumption, it indeed seemed to follow that the core of the interpretive enterprise depended on the most accurate chronological data. As Boeckh laments apropos of Nemean 8: "The fact that nothing survives in the scholia about the date when this exceptional ode was written is thoroughly irritating, since the subtler interpretation of the ode depends almost entirely upon this question" ( 1963 [1821]: 440). No wonder it seemed to Boeckh and his followers their "manly duty" (pro virili, 440) to extort by any means possible from the body of available historical data about Pindar's lifetime the most probable configuration of events in terms of which to carry out this "subtler interpretation."

Since our knowledge of the circumstances of any particular ode is indeed a function of the availability of data, in particular chronological data, and since Pindar is the first figure we are considering about whom there $i s$ something approaching such data, it may be useful to examine briefly the nature of the evidence and its early analysis. 
Consciousness about chronology seems itself a phenomenon first emerging in the fifth century along with the Sophists and the first historical essays. Hippias published the first list of Olympic victors (Bickerman 1968: 75) during the second half of the fif th century; Aristotle compiled a list of Pythian victors c. 335-34 B.c. In the case of the Olympian and Pythian odes, the ancient scholia normally specify the Olympiad or Pythiad in which the victory celebrated in the ode was won (Gaspar 1900: 10). An Oxyrhynchus papyrus fragment listing Olympic victors happens to give corroborative information for ten of the fourteen Olympian odes, solving some dilemmas arising from corruptions in the manuscripts of the scholia (Gaspar 1900: 11). For the Pythiads, however, there is no such supportive prop but apparently also less evidence of corruption (Gaspar 1900: 10). Apart from these indications, the only bases for dating the odes are extrapolations from alleged references to events known from other sources. The indisputable allusions vary from the quite explicit reference to the battle of Salamis (Isthmian 5.48-50), to the metaphor of the stone of Tantalos (Is. 8.9-12), universally taken as a figure for the Persian menace, to the concrete but highly problematic allusions to the deaths in battle of relatives of the victor (Is. 4.16-18, 7.24-26).

Since there are few unequivocal allusions, the major problem arises with those scholars-from Boeckh to Bowra-who have attempted the circular operation of perceiving an echo of a political situation and then interpreting and dating the ode in the light of the alleged political context. Bowra, for example, following Wilamowitz-Moellendorff (1966 [1922]: 311 ), sees "hints of a disturbed situation after the death of Theron" (1964b: 410 ) and evidence of "the changed situation at Acragas" involving "a certain menace" in the following lines of Isthmian 2:

Now, because envious expectations hang about the minds of mortals,

Do not ever silence the excellence derived from/belonging to your father [patröian],

Nor silence these songs. For not to

Rest unmoved did I work them out for you.

(Is. $\left.2.43^{-4} 6\right)$

One can produce many such speculations about "political uncertainties," "an air of apprehension," or other "echoes of politics" (e.g., Bowra 1964b: 99-1 58, 4o6-13), which are by no means necessary allusions. Moreover, in the case of odes for which there is no other obvious indication of date, the conclusions drawn about chronology are so wildly different as to invite us to abandon entirely the exploration of 
Pindar's relation to his social and political context. Nemean 8 is a particularly striking example. Gaspar (1900: $4^{2-45}$ ) gives a date of $491-a$ year earlier than Pythian 10, the earliest ode for which the scholiasts specify a date; he is following Mezger (180o: $325^{-26}$ ) in seeing clear allusions to the bitterness of Athens after the Aeginetans gave earth and water to Darius' envoys. Bowra, who puts the ode with a question mark in 459 (1964b: 412$)$, follows Bergk in seeing evidence of old age; but unlike Boeckh (1963 [1821]: 440-51), who put it in $45^{8}$ after the battle of Kekryphaleia, Bowra is not sure that war had yet broken out. Brown (1951: 13) argues for a date of 445, a year after Pythian 8, the last ode dated by the scholia. The questionable relevance of stylistic criteria for dating (e.g., Theiler 1970: 148-91) is suggested by Schmidt's claim (1973: 430) that Nemean 8 was a work of the poet's youth whereas others set it very late in Pindar's career and find the appropriate signs of his "mature" style.

Indeed the confidence of the historicizers is at times so great that they even dismiss the scholiasts' designations of specific dates. Gaspar (1900: 165 n. 3) notes for example that Otfried Muller, Thiersch, and Boeckh do not hesitate to challenge the scholiasts' dating of Pythian 8 on the basis of their interpretation of of the word eleutherō ("free") in line 98 as incompatible with the domination exercised by Athens over Aegina in the scholiasts' date of 446 . The fact that there are many clear examples of corruption in the transmission of numbers in ancient Greek manuscripts of very different sorts may encourage one to doubt any date that has no external corroboration, so that all the Pythian odes are in principle vulnerable to this sort of assault. But to the extent that the older historicizers' assumptions led in such a direction, the entire historicizing enterprise threatens to self-destruct.

\section{Bundy's Way out of the Political}

Although one of the more militant followers of Bundy has harshly denounced anyone who speaks of Bundy and his followers as engaging in rhetoric, not scholarship (W. Slater 1977: 193), ${ }^{16}$ I believe it would be all but impossible to overestimate the impact of Bundy's work on the way we all read Pindar. ${ }^{17}$ Bundy left the dichotomy between form and

\footnotetext{
${ }^{16}$ I console myself with the thought that W. Slater also declared that encomiastic poetry itself is "basically rhetoric" (1977: 195), a position with which I am in some sympathy if by rhetoric one means what Eagleton (1983: 205-6) seems to mean by it.

${ }^{17}$ Any consideration of modern Pindaric scholarship is much indebted to D. C. Young's ground-breaking "Pindaric Criticism" (1964), which, for all its apparent eclecticism, went a long way in supporting the logic of accepting Bundy's way as the foundation of any strategy for reading Pindar.
} 
political content behind only to the extent that he succeeded in convincing readers that the specific historical, social, and political contexts of the odes are relevant only as poetic functions of the all-explaining laudator-laudandus relationship in each poem. Aspiring perhaps to become the Milman Parry of Pindaric studies, he attacked his own version of the "Pindaric problem," which he argued results from our forgetting

that this is an oral, public, epideictic literature dedicated to the single purpose of eulogizing men and communities; that these eulogies are concentrated upon athletic achievement, that the environment thus created is hostile to an allusiveness that would strain the power of a listening audience, hostile to personal, religious, political, philosophical and historical reference that might interest the poet but do nothing to enhance the glory of a given patron. (1962: 35 )

The root of our latent neglect of "the plain requirements of genre" is, he suggested, in "our distaste for the genre itself" (35). Bundy's solution to this problem was a brilliant elucidation of what amounted to the formulaic nature of the poetry of both extant epinician poets, Pindar and Bacchylides, focused single-mindedly on strategies of praise for the victor. Bundy's great achievement was to restore a basis for elucidating one formal level of unity inadequately recognized by previous scholarship. That basis was "the fulfillment of a single purpose through a complex orchestration of motives and themes that conduce to one end: the glorification, within the considerations of ethical, religious, social and literary propriety, of [the] victor" (91).

An admirer of Bundy's has stressed quite rightly that the formulations cited above do not exclude politics from the interpretation of Pindar (Lee 1978: 65-70). ${ }^{18}$ Yet the strategy of those who are most indebted to Bundy's approach is most revealingly clear when they deal with the relatively few undeniable allusions to concrete political events. In these cases, the followers of Bundy have ably demonstrated Pindar's and Bacchylides' technique of translating specific historical and social

\footnotetext{
${ }^{18}$ Lee (1978: $65-70$ ) begins by objecting to my characterization of Bundy (Rose 1974: $145-75)$. Yet in defending Bundy from the implication "that praise is the exclusive function of the elements in an ode," he cites this same article of mine for proof that "gnomic statements, often with mythical exempla, may serve a general paideutic function or a more narrow one of propounding aristocratic values" $\left(6_{7}\right)$. This strikes me as curious in as much as my chief criticism of Bundy is that he and his followers generally ignore all but the function of "praise," conceived in narrowly athletic terms. Thanks to the kindness of William Race, I have had an opportunity to read Bundy's doctoral dissertation (1954). It is fascinating to trace the process by which he moves from acknowledging obviously political dimensions of the odes toward ever narrower focus on the purely encomiastic dimensions.
} 
data into the realm of myth. The victor's battle-slain uncle becomes a mythic paradigm on a par with figures from Homeric saga (D. C. Young 1971: esp. 45-46) just as King Kroisos (Bacchylides 3) is transported by the gods to the Hyperborean utopia. In response to the chronologically based arguments of earlier scholars such as Bowra, they have had no trouble demonstrating that alleged evidence occurs not infrequently in entirely conventional elements of the laudatorlaudandus relationship. Bowra's interpretation, for example, of the reference is Isthmian $\mathbf{2 . 4 3}$ to "envious expectations" would strike a follower of Bundy as a particularly ridiculous instance of a failure to recognize the purely traditional phthonos motif (Bundy 1962: 12, 15) combined with the equally predictable reminder of the poet's task. ${ }^{19}$

Neither Bundy himself in his regrettably exiguous published work nor those scholars who have followed him have chosen to explore the ideological content of Bundy's criterion of "ethical, religious, social and literary propriety." They have not considered the ideological function of Greek athletic activity itself nor the praise of it by epinician poets. They have rarely examined the ideological grounds on which "personal, religious, political, philosophical and historical references" might be interesting to both a patron and the poet. ${ }^{20}$ On the contrary, the whole thrust of Bundy's discussions of Pindaric abstract vocabulary - that aspect of his poetry most clearly suggestive of values-is to demonstrate their concrete reference only to the encomiastic situation. Indeed, the whole direction of Bundy's doctoral dissertation (1954) was to demonstrate how an apparently very political term like Hesychia as it appears in the invocation of Pythian 8 should be divested of its po-

${ }^{19}$ Thummer (1968: 19-158) and Hamilton (1974: 14-25) offer what I consider particularly pure examples of Bundian accounts of the structure of the typical Pindaric ode. For the place in this structure of the "poet's task," see Hamilton: esp. 16-17.

${ }^{20} \mathrm{D}$. C. Young (1971) is a notable if only partial exception. More recently Hubbard, a self-proclaimed student and follower of Bundy (1985: vii, 2-3), has shown occasional interest in explicit political allusions (e.g., 86 n. 43). But the chief aim of his intelligent study of the "pindaric mind" is to elucidate the process by which Pindar makes his paradigmatic choices within an essentially Bundian syntagmatic axis $(9-10)$. To echo Marx on the Young Hegelians, Hubbard has not inquired into the connection of this mode of thought or series of polarities and ancient Greek reality, the connection of Pindar's paradigmatic choices with the material circumstances of both poet and audience (MECW $5 \cdot 30)$. Glenn Most has elegantly juxtaposed the historicizers of the old school and the followers of Bundy under the respective rubrics of "uniqueness" (emphasizing the unique historical event as the source of explanation) and "conventionality" (emphasizing the regularities of the genre or the corpus as the basis of interpretation). He points out that "their interpretative practice always consists of deferring to inf inity the effective intervention into their discourse of that side of the opposition they reject" (Most 1985:30). The alternative he himself describes in his methodological introduction under the rubric "immanent compositional unity" (42) appears, from his self-association with "especially Köhnken and Young" (47) and from his illustration in the analysis of Isthmian 1, to be essentially a sensitive and intelligent application of the old New Criticism. 
litical associations and recognized rather as "agonistic, with reference to the peace which follows upon the outlay of labor and expense toward a successful conclusion" $\left({ }_{158)}\right)$. In his published study, Bundy is more clearly at pains to stress the solely agonistic/celebratory reference of Pindar's abstractions: "No commentator will inform his readers that Euphrosuna in Nemean 4.1 (personified abstract for concrete) is a poetic word for a victory revel" (1962: 2). The Greek word phua, which had long been recognized as in some sense the distillation of Pindar's ideological commitment to inherited excellence, is glossed by Bundy as "the natural enthusiasm" of the laudator for his theme, the laudandus.

It does not in any way diminish Bundy's extraordinary contribution to underline the fact that his critical assumptions are themselves intimately related to a historical moment. His work represents in the instance of Pindar the culmination of the gradual conquest of classical philology by Anglo-American New Criticism, a school of criticism that in English literature was already beginning to self-destruct by 1957 (Lentricchia 1980: $3^{-26}$ ). One may say that in relation to the posture toward the reading process, its founding moment is the centrality of the opposition of what is extrinsic and what is intrinsic to the text. Wellek and Warren, for example, in their tremendously influential Theory of Literature (1956 [1942]), dub as extrinsic everything pertaining to biography, psychology, society, and other arts, whereas the intrinsic includes euphony, rhythm, meter, style, images, metaphors, symbols, myths, and genres. Without rushing to a premature dismissal of the potentially valid arguments underlying such a distinction, it is important in this context to notice the convenient fit between this radically antipolitical position and the entire intellectual climate of the Cold War-obsessed, McCarthyite 1950s.

If we are to restore the ideological content of the odes as a legitimate aspect of the analysis of their poetic meaning, it cannot be on the preBundian level of positing scraps of political allusions divorced from poetic texture or citing scattered sententiae out of context, then either openly denouncing them with Norwooden irony or tacitly endorsing them in the process of explicating them (e.g., Jaeger 1945: 205; J. H. Finley 1955: esp. 155) ${ }^{21}$ Fränkel's insistence (as early as 1930) that unity be sought on the level of values (1973: 350-69, esp. 366 ) is neither superseded by nor incompatible with Bundy's vague invocation of propriety; it at least implicity recognizes the deeper problem,

\footnotetext{
${ }^{21}$ In addition to $\mathrm{M}$. I. Finley and Norwood, other notable practitioners of the denunciatory approach are Beye (1975:1 26-27) and Bilinski (1959:43-45). The latter, despite his primary interest in the ideological function of Greek athletics, devotes less than three pages to Pindar and ends his comments (as Beye begins his) by citing with approval Voltaire's scathing apostrophe to Pindar, cited as well by Norwood (1956: 240).
} 
untouched by Bundy, of the relevance of athletics and praise of athletes to Pindar and his audience. ${ }^{22}$

\section{Pindar and the Double Hermeneutic}

The way out of the dilemma between a political judgment that simply either dismisses or endorses Pindar and an aestheticism that simply brackets the political dimension lies, it seems to me, along the lines of the double hermeneutic discussed in the introduction-an exploration of all the ways the text participates in partisan ideological struggle on behalf of the class position of the Greek aristocracy and at the same time all the ways it transcends and negates that position. Pindar is in this sense only an extreme example of a problem which, I have suggested, is really characteristic of any modern appropriation of ancient texts. ${ }^{23}$

The first advantage of applying a double hermeneutic to Pindar is that it recognizes the validity, even the necessity, of taking Pindar's politics seriously as an integral element of his poetry. This stance in turn implies the responsibility to seek as clear an understanding as one can of the social, political, and economic forces at play when Pindar composed his poetry. It renders chronology its due, but on a rather different basis from the old historicizers. Obviously, the more precisely one can understand the immediate circumstances of an ideological response, the more resonances with those circumstances one is tempted to perceive. Yet the older historicizers were committed to a definition of politics almost exclusively tied to concrete events in an on-going struggle conceived primarily as inter-polis bids for power. Although they were aware of the pervasive conflicts at the political level of democracy and aristocracy, they had an undertheorized conception of the class character of ideological struggle and how such struggle is conducted. At the level of ideological struggle, the inherently more structural sources of conflict dictate a more indirect, indeed of ten a more

${ }^{22}$ D. C. Young, in his revised version of "Pindaric Criticism" (1970: 66), has added a graceful and well-deserved tribute to Fränkel's merits as a critic and explicator of Pindar's thought. Yet, in relation to the question of unity, he has merely softened his earlier judgment that Fränkel's discoveries are "pitifully insignificant" to "rather insignificant." Fränkel's view that unity cannot reside in the individual ode but rather in the system of values revealed by the corpus of odes as a whole (1973: 489-9o) violates the New Critical dogma of the organic unity of each artwork. Yet the Bundian version of the unity of an individual ode is inconceivable without relentless cross-reference to the systematic procedures that become clear only within the framework of the whole corpus. Their approach is thus radically "intertextual" malgré eux.

${ }^{23}$ I take it as a sign, however, of the peculiar appropriateness of this solution to Pindar that it has found favor with so eminent and critically eclectic a Hellenist as Charles Segal (1986a: 127 n. 12), albeit with a reversed political valence: for Segal, what the Marxist negative hermeneutic unveils is positive, and vice versa. 
abstract mode of discourse than that focused on the interpretation of specific political events (this more abstract discourse used to be called "Panhellenic paideia"). But an essential part of this indirection is at the level of form and the relation of that form to the conditions of cultural production, performance, and reception. We cannot simply spell out an explicit political content; rather, the double hermeneutic compels us to deal fully with the epistemology of artistic form, to see the ode not as mirroring the reality defined by the Greek aristocracy but as a significantly autonomous transformation and transcendence of that reality. The ode's relative autonomy is an inevitable consequence of its formal, sensuous aspects-its relations to a whole range of signif ying systems such as meter, music, all the conventions of the specific genre as well as the entire Greek poetic and ritual tradition, all of which constitute in various ways intractable interference to unmediated reflection of a completely external reality.

\section{The Epinician Form}

A word first on the occasion of the genre, the games themselves. The games may well have originated in the ritual cult of the dead and been nourished by ancestor worship. ${ }^{24}$ But, as we have already noted, their organization on a grand scale and their insertion into the whole nexus of poetic paideia is most plausibly understood as an ideological gesture by the aristocracy in response to their loss of a literal role as "those who protect cities" (cf. Il. 9.396; see also 6.403, 16.542). We cannot say with any certainty when epinicia began to be composed to guarantee that the achievements of the victors be adequately appreciated and preserved, but the first known epinician dates from 520 B.C. and was composed by Simonides. The inference that he invented the genre is only an inference, but plausible. The founding gesture of the genre is to apply to a human achievement an old art form previously devoted to the praise of gods and heroes (Fränkel 1973: 434). D. C. Young has recently argued for the non-aristocratic origin of the earliest known recipients of epinicia (1985: 142, 155, 174; Lesky 1966b: 186; contra Bilinski $1959 ; 43)$. Given the democratic sympathies regularly attributed to Simonides and the rather playf ul tone of surviving fragments (Fränkel 1973: 435-36), it may not be amiss to recognize that the genre at the earliest point we encounter it is already constituted as an arena of ideological struggle. Indeed the founding gesture alluded to above

\footnotetext{
${ }^{24}$ See Meuli 1941 and Yalouris 1979: 82-84. D. C. Young (1985: 12 n. 72) is extremely skeptical about a religious origin, but his invocation of a "Greek nature" (175) is not helpful and ignores the clear effort to associate the games with religious festivals.
} 
makes sense as more than aristocratic self-advertisement; it also makes excellent sense seen in the context of the emerging humanism of the Presocratics and the growing confidence of the hoplite class. Just as arbitrary divine causality begins to recede in the physikoi, so the Simonidean epinician may have celebrated purely human achievement in contradistinction to the mythic claims for gods and the sons of gods. In any case, the institutionalization of the games themselves, their success in defining the values of "all the Greeks," and in particular their heavy support from public funds were clearly matters of discursive conflict, as we have already noted in the case of Xenophanes and earlier of Tyrtaios. ${ }^{25}$

Whatever the necessarily tentative conclusions one might draw about Simonides, in Pindar the whole elaboration of the form is directed toward affirming the strict hierarchy of "god, hero, man" (cf. Ol. 2.2) and presenting any celebration of the victor's community in terms that clearly subsume the distinction of the polis under the distinction of its rulers. If D. C. Young has compelled us to abandon the automatic assumption that all participants in the games were aristocrats $(1985)$, it is worth repeating that Pindar's patrons included some of the most powerful and politically most oligarchic (cf. Andrewes 1956: 129-36) tyrants and kings (Segal 1986a: 13-14) as well as reigning oligarchs (e.g., the Aleuadai) in the Greek Mediterranean world.

More relevant is the way Pindar structures into his odes the aristocratic concept of inherited excellence. Schadewaldt long ago suggested that the basic point of departure for the development of the epinician form was the concrete historical experience of the victory, with its formal proclamation of the victor's name, father, and homeland (1966 [1928]: 3-4). Pindar chooses to integrate the achievement of the victor with his origin. I count twenty-three odes out of the surviving fortyfour in which the excellence of the victor is explicitly presented as inherited from the heroes of his homeland: Olympian 2, 6, 7, 8, 10, 11 ; Pythian 4, 5, 9; Nemean 2, 3, 4, 5, 6, 7, 8, 10, 11 ; Isthmian 1, 3/4, 5, 6, 8. Of these, all but Olympian 9 and Nemean 3 also emphasize a purely literal sense of inherited excellence by associating the victor's achievement with those of his relatives or family line. In Olympian 9 and Nemean 3, where presumably the family of the victors was not sufficiently distinguished to permit praise of a specific heritage, Pindar is nonetheless strikingly emphatic in proclaiming the principle of inher-

\footnotetext{
${ }^{25}$ I find it suggestive of this conflict that the final event at the Olympic games was a specifically hoplite event, the race in armor (Yalouris 1979: 133). Though I have encountered no comment on the point, it seems to me plausible that this reflects an insistencewell after the order and character of the other events had been established-on the relevance of specifically hoplite aretē to this arena of testing.
} 
ited excellence $\left(\mathrm{Ol} .9 \cdot 100-104 ; \mathrm{Ne} \cdot 3 \cdot 40-4^{2}\right)$. Moreover, in such poems as Pythian 8 and Nemean 1 (Rose 1974), in which the myths are not metaphorically grafted onto the victor's family tree, they are presented as confirmations of the principle of phua, a term to which, as noted, Pindar made a special contribution.

We may recall here that scholars tracing the trajectory of phusis/phuél phua have regularly singled out Pindar's heavy emphasis on the term. Following these approaches, we may say here that on this linguistic level the originality of Pindar seems to have consisted in grafting onto the Presocratic notions of reliability, fixity, and normality the aristocratic pride in special birth/growth from a specific ancestry. But simply to focus on the single word is to miss the extraordinary richness and amplification that phua and associated notions gain in context from Pindar's entwining them in a uniquely rich network of kinship/birth/ begetting terminology and vegetative and sexual imagery with which he insists on the genealogical principle. Consideration of this vocabulary should include terms denoting "inborn" (phua, sungenēs, sungonos, sumphutos, emphuess, emphulios, gennaios, gnēsios), terms denoting the victor's family members, family, clan, or tribe (haima, genea, genna, genethlios, genos, domos, ethnos, matradelpheos, matēr, matrodokos, matrothen, matromatōr, matrōs, patēr, patradelpheos, patrios, patrōios, patropatōr, progonos, oikothen, oikos), terms for offspring (pais, gonos, ekgonos, aristogonos, teknon, thalos), terms for the physical process of the transmission of excellence (phūo, phuteuō, mignumi, ginomai, tiktō, gona, sperma, Eleithuia). If to these were added all the proper names that associate the victor's excellence with that of his relatives, his homeland conceived of as a mother, his homeland's heroes conceived of as ancestors, and if then full consideration were given to the imagery of plants (McCracken 1934; D. Steiner 1986: 28-39) and fields fused with imagery of human reproduction (Hoey 1965), one might begin to get some sense of the unique impress of this doctrine on the fabric of Pindar's handling of the epinician. ${ }^{26}$ Surely we are dealing with something more than the natural enthusiasm of the laudator for the laudandus. ${ }^{27}$

\footnotetext{
${ }^{26}$ It is a characteristic mark of the power of Bundy's influence that D. Steiner begins her discussion of the metaphor of plant life by assuring us that "it emerges naturally from the context of the Games, suggested by the crown of leaves which the triumphant athlete wore" (1986: 28).

${ }^{27}$ D. C. Young (1 $968: 113$ n. 4) rather grudgingly acknowledges that there are grounds for attributing an aristocratic belief in "blood" to Pindar, but he suggests that the difference between him and Bacchylides is not overwhelming. He proceeds to invoke a "Greek belief in something like genes," but neither blood nor genes is adequate to the rich and heavy sort of emphasis throughout Pindar's epinicians. Such concepts also fail to account for Pindar's persistent penchant for fusing literal genealogy with metaphorical descent from the local heroes.
} 
Bacchylides' surviving epinicians may be too few and too fragmentary for an adequate comparison on this count, but what evidence there is suggests to me an overwhelming difference (cf. D. C. Young 1968: 113 n. 4). Beside Bacchylides' apparently occasional use (1.1 40$\left.5^{1}, 2.8,9.47-5^{2}\right)$ of a probably traditional motif stands Pindar's systematic and consistent transformation of that motif into an organizing structural principle of the ode and a vision of reality. Most revealing is the contrast between Bacchylides' 1 $3^{\text {th }}$ Ode and Pindar's Nemean 5, both composed for the same victory. Bacchylides celebrates the heroes of the island yet never presents their excellence as explicitly the victor's by birth, nor does he refer to other victories in the specific family of the victor. In Pindar's poem, the victor "honors the Aiakids and the city of his mother" (8). The myth celebrates a marriage of an Aiakid (Peleus) won by virtue, and the victor "falls in the arms of Victory (Nikē)" (42). His uncle honors him, "a scion of the same stock as Peleus" (43, trans. Bowra). Lest anyone miss the point, the poet declares, as he moves from the myth back to the victor, the explicit moral to be drawn: "The fate that is innate proves decisive in all actions" (potmos de krinei sungenès ergōn peri/pantōn, 40-41, where the enjambment gives weight to pantōn). The core of the overwhelming majority of Pindar's odes thus emerges as a meditation on the links between the specific achievement of the victor, his immediate origin in his own family, his more remote origin in the mythically evoked heroes of his homeland, and, finally, the origin of both those heroes and the present victory in divine favor.

The qualities (aretai), both physical and ethical, which are celebrated within this framework - strength, daring, military prowess, foresight, hospitality, justice, and generosity-are presented as characteristic of the victor. But they are neither exclusively athletic nor apolitical essences. The consistent generalizing cast of Pindar's language, which presents the games themselves in such vague terms as "toil" (ponos), "trouble" (kamatos), "expenditure" (dapana), "reward" (apoina), or "happiness/wealth" (olbos), invites those in the audience who have the requisite wealth for such expenditures and efforts to find a comforting reflection of themselves in the inherited excellence of the victor. So too Pindar's clear preference for myths drawn from the panhellenic epic tradition (Davison 1968: 301-2) and encompassing a range of human activity vastly broader than athletic contests, the apparent source of Simonides' epinician myths (Fränkel 1973: 435), or even warfare seen as the doublet of athletics (D. C. Young 1971:39-42) constantly invites the audience to perceive a message that transcends the immediate contest. Moreover, Pindar does not simply repeat the old heroic myths; he both moralizes them-thus implicitly responding to such critics of myth as Xenophanes-and integrates them into his utopian projection 
of an ideal aristocratic world, where birth is the determining principle of everything worth having. ${ }^{28}$

At the level of language and meter, Pindar represents the culmination of a specifically aristocratic appropriation of the new possibilities opened by literacy. ${ }^{29}$ Nothing is formulaic in Pindar except the sorts of rhetorical strategies and linkages explored by Bundy and his followers. The common store of oral formulaic language is echoed only to reinforce the celebration of individual originality. Thus, for example, the familiar epic formula "winged words" (epea pteroenta) is never used as such by Pindar but is characteristically presupposed and played with in such locutions as his self-exhortation to let fly a metaphorical "sweet, winged [pteroenta] arrow" from "the far-darting Muses' bow"; he will not set his hand to "words that are groundward-falling" (khamaipeteōn) (Ol. 9.4-12).

The situation with meter is much the same. Pindar's preferred dactylo-epitrites echo the cadences of epic hexameters and in particular the hemiepes (long/short/short/long/short/short/long). This is a very common initial unit of the epic hexameter (cf. Mènin aeide thea, Il. 1.1); doubling the hemiepes makes the second line of the elegiac couplet. The hexameter and the elegiac couplet were meters which, in principle, were available to every reasonably talented amateur. So too the Aeolic meters are built on what in all likelihood were simple folksong meters. ${ }^{30}$ Yet each ode is the occasion for a dazzling display of unique originality: no two have exactly the same configuration. ${ }^{31}$

${ }^{28}$ See especially Pini 1967, Thummer 1957: esp. 12-20, and D. C. Young 1968: 34 . Huxley puts the case baldly and perhaps backward, but as far as it goes, justly: "Because the poet's patrons had divine ancestry, they were living witnesses to the truth of the Olympian system; aristocracy had the hereditary blessing of the gods themselves, and so Pindar's religion was politically authenticated-there is analogy here with the old adage that the Church of England is the Tory Party at prayer" (Huxley 1975: 7). Huxley's chap. 2, "The Editorial Poet" (1 4-22), offers a usef ully concise overview of Pindar's corrections and suppressions of myths that compromise moral claims for the Olympians, heroes, and, by implication, the aristocracy.

${ }^{29}$ Here I disagree with Havelock's $(1982: 16)$ endorsement of Fennell's idea that "it is probable that he did not write his odes." It may be correct to suggest a connection between a "grand style" and Pindar's sense of a "burden of social responsibility" linking him with Homer (1986: 120); but, as I suggest above, the texture and complexity of Pindar's compositions-like his extreme self-reflexivity - are best understood as a consequence of new, specifically literate possibilities. Gentili's emphasis on oral performance (1988: esp. 4) seems to me more relevant and more productive.

${ }^{30} \mathrm{I}$ am aware of the deep scorn reserved for even the most tentative efforts at historicizing Greek meter by the great empiricists who have dominated the field (e.g., Dale 1969: 52). But, as Whitman observes in his foreword to Nagy's brilliant exercise in historical metrics (Nagy 1974: xi), "no known culture evolves the long, elaborate epic before its bardic priests address hymns to the gods and mothers sing their children to sleep."

${ }^{31}$ The fact that Isthmian 3 and 4 have the same metrical structure is one of the strongest grounds for seeing them as one poem or as a specially related pair of poems. Bowra (1964b: 317 ) cites these two (printed by Snell as a single poem) as the apparent exception proving the rule. As Dale observes more generally, "the repeating triads ... give a much 
It is not ignorance or insensitivity that leads so many readers to confuse the individual voice of the poet with the traditional communal voice of the chorus. ${ }^{32}$ Pindar's sustained reflexivity on his own poetic activity and his constant parallelism between himself and the victor affirms the aristocratic, heroic ideal of individualism in its most hierarchical, winner-take-all form. It is no accident that Pindar's is the first surviving text to articulate the opposition of "born" poet and the mere "learner" (Ol. 2.86-88; Ol. 9.100-104; $\mathrm{Ne} .3 .40-42)$. We noted a bare hint of self-reflexivity in the poet of the Iliad, a rather striking if only implicit self-reflexivity in the poet of the Odyssey, and finally in Hesiod the first outright, if short-circuited, confrontation of the role of the poetic text in constituting the very reality that it purports to represent passively as the gift of the Muses. Pindar comes after a long development of ever-increasing consciousness among poets about the social functions of their work and the role their texts play in establishing alternative versions of reality. His own exalted sense of his poetic mission (Gundert 1935), while unquestionably integrated with his function as praise-poet, has the effect of inviting his audience-perhaps especially his future audience-to an exclusive focus on the sheer dazzle of his performance as a poetic technician. Since his usual posture is as a guest-friend of the victor or the voice of the victor's whole community, his partisan ideological role is correspondingly masked in the text.

I have emphasized these aspects of the typical structure and content of Pindaric odes because, even within the dubious limitations of the New Critical idiom, I believe that they are intrinsic to Pindar's handling of the form. As a confirmed New Critic and devoted admirer of Bundy has conceded,

the achievement of Pindaric criticism in the last two decades has been to clear the odes of the extraneous historical and biographical matter that had been read into them. The danger is that critics may now be reading out of the odes a good deal that is really there and in the process impoverishing rather than purifying them.... Somewhere along the line ... the question comes: how much has to be excluded as irrelevant to the poet's encomiastic task? ... What about matters which, while they may be of no immediate or obvious bearing on the victory that is being celebrated, may be of active concern to the victor and his community? The victor was after

needed check for the determination of period end; no calculation, no schematic patterns, and no appeal to rhythmical sense on our part could without this check give any assurance that we had found the right shape for a single stanza of this arbitrary, deliberately unsymmetrical, constantly inventive poetic technique, which gives to each ode its unique, neosigalon tropon [new-shining style]" (1969: 45).

${ }^{32} \mathrm{On}$ this vexed issue, see Lefkowitz 1963 and 1975 b: 8o-81, Fränkel 1973: 427, Bundy 1962: 69-70, esp. n. 84, W. Slater 1969: 89-91, and Hamilton 1974: $113^{-15}$. 
all a citizen, bound up with the life of his city to a degree we can scarcely picture. (Carne-Ross 1985: 184-5)

To return now briefly to what is "outside" the text but brought "inside," that is, specific allusions to political events and the political or military role of individuals in them, Bundians seem to feel that if they can demonstrate how history is transformed into allegedly universal categories they have done with politics. But this transformation is itself a key strategy of ideological mystification: to the extent that a particular class succeeds in presenting its interests, its vision of reality, as the universal vision of the human condition, it precludes the challenge of alternative visions. On the other hand, it is worth recalling that the specific means by which a particular literary work may be immersed in its historical moment are not susceptible to a priori techniques of interpretation. As Jameson rightly argues, "there can be no preestablished categories of analysis: to the degree that each work is the end result of a kind of inner logic or development of its own content, it evolves its own categories and dictates the specific terms of its own interpretation" (1971: 333).

\section{Toward a Double Hermeneutic of Pythian 10}

Before applying some of the preceding generalities to the text of a specific ode, I stress again that the double hermeneutic is not neutral. The negative hermeneutic explores all aspects of the text that support and reinforce a regime that uses both the repressive apparatuses of the state (military force, etc.) and the ideological state apparatuses to retain a disproportionately large share of the socially created surplus in the hands of a small portion of the society. The positive hermeneutic seeks to uncover those aspects which, in the perspective of the long movement of history, open a realm of human freedom and are capable of contributing to a perception of the inadequacy of the status quo, thereby fostering the principle of hope.

\section{The Negative Side}

What specifically do we know of the immediate political context of the ode? Pythian 1o, Pindar's earliest extant ode according to the indications of the scholia, is dated to the $22 \mathrm{~d}$ Pythiad ( 498 B.C.). ${ }^{33}$

\footnotetext{
${ }^{33}$ Drachmann 1964 (1903): 241 . Why Gildersleeve (1965 [1899]: 348 ) says 502 B.C. is beyond me.
} 
Although no Pythian victory date is independently confirmed, references in Herodotus $(7.6 .2,7.130 .3,7.172 .1,9.1 .1,9.58 .1-2)$ to Thorax and the Aleuadai confirm a date well before the coming of the Persians. The victor was a Thessalian boy named Hippokleas, who had won the double footrace (approximately 400 meters) at Delphi. Although an allusion in the text (18) implies that the victor's family was impressively wealthy - an inference in any case from his horsey name ( hipp-,"horse"), the ode was commissioned not by the boy's father but by Thorax of Larissa $(5,64-65)$, a member of the ruling Aleuadai clan and tagos, appointed "king," of Thessaly. ${ }^{34}$ For roughly a century before the Persian wars catapulted Athens into strategic prominence, "the revival of the military powers of kingship made Thessaly the leading state north of the Isthmus" (Hammond 1959: 142).

If we now consider somewhat more closely what I have pretentiously called the epistemology of artistic form in connection with the Pindaric epinician, we find contemporary analysts debating the relative weight to be given the "linear argument" and the role of verbal echoes or patterns of imagery (e.g., W. Slater 1977: 193-95). I would say that much of the power of Pindar's handling of the form derives from the tension between the forward thrust of the praise program and the quality of a static vision effected by the extraordinarily rich tapestry of echoes, cross-references, and direct repetitions (Greengard 1980). But there is general agreement among post-Bundians that the essential technique of the epinician poem, its rhetorical structure, consists in praising the victor by establishing a series of parallels and associations between, on the one hand, the specific action of the victory, the excellence of the victor, the victor's family and homeland, and, on the other, a broad range of usually positive phenomena. Negative phenomena, it is argued, enter only as dark foils, by virtue of which the achievement of the victory only shines the brighter (Bundy 1962: 40, n. 16; Köhnken 1971: esp. 34).

A relatively fixed set of expectations and rhetorical postures on the part of the poet organizes these associations, parallels, and contrasts. Thus a recent study of Pindaric form breaks down Pythian 10 as follows: Homeland Praise; Poet's Task with Breakoff Formula; Poet's Task-Naming Complex-Victor Praise; Gnome (i.e., a generalizing statement); Victor Praise-Other Praise; Future Prayer; Gnome-Gnomic Cluster-Myth; Gnome; Poet's Task with Breakoff Formula; Poet's

\footnotetext{
${ }^{34}$ Wilamowitz-Moellendorff remarks (1966 [1922]: 123) that the term "king" is not strictly correct since the role of tagos was appointed. He concludes therefore that it is laudatory. This seems a reasonable inference, but we should note that Herodotus designates all the Aleuadai as basilees of Thessaly (7.6.2), presumably in the loose Odyssean sense of "oligarchs."
} 
Task-Victor Praise; Gnomes; Poet's Task-Other Praise; Gnome; Poet's Task-Other Praise; Gnome (Hamilton 1974: 91) ${ }^{35}$ It is perhaps too easy to ridicule this "computer" model of Pindaric structure (Lefkowitz 1976b: 340-41). My only concern as I embark on a negative hermeneutic of the poem is to stress that $I$ begin from a relative consensus about what is intrinsic to the ode. Though I tend to find more value in Fränkel's proposition that the coherence-I would add the excitement - of an ode derives in large measure from Pindar's concern to demonstrate "an immense number of individual connections of all kinds and directions" (1973: 496), we are well served too by the demonstration that this process takes place within the tight framework of a small number of fixed rhetorical strategies employed again and again throughout the odes and linked by the laudatory function.

The basis of my negative hermeneutic is simply to indicate some of the major, of ten overlapping connections established in the poem and to suggest their partisan ideological import. The first and most dramatic connection between the felicity of this teenage athlete and the world beyond the racetrack is to associate the former with the political felicity of his homeland. The blessedness of Thessaly is boldly linked with the prosperity of the supreme power in Greece, Sparta: "Prosperous is Lakedaimon, / Blessed is Thessaly" (1-2). The specific basis for this political felicity is their form of government, inherited monarchy, traced to the same Dorian ancestor, Herakles: "From one [i.e., the same] father for both [Sparta and Thessaly] a race from Herakles bestin-battle rules royally [basileuei]" $(1-3)$. The epithet of the founding patriarch Herakles-"best-in-battle"-emphasizes approvingly the military dominance particularly characteristic of the Dorian aristocratic regimes in general and of Thorax in particular, whose very name, "Breastplate," suggests his family's obsession with warfare. Given that Thessaly's ruler was not exactly a monarch by inheritance but was in fact appointed as tagos and to some extent constitutionally controlled (Larsen 1966: 40-41), this linkage may involve some special pleading.

Pindar's next association combines the site of the victory, the site of the victor's home (presumably), and the ruling family of Thessaly as jointly imposing the task of praise on the poet:

Why do I boast unseasonably? Because Pythō [Delphi]_And the Pelinaian [a city of Thessaly] as well-cries out to me,

\footnotetext{
35In Hamilton's schema dashes indicate "a connection between parts" (1974: 89). The nature of the connections and whether there are connections with parts not connected by dashes are more or less moot points in his study.
} 
And the sons of Aleuas, wishing that for Hippokleas' sake I escort the voice of men that brings festivity and fame.

The personification of places dramatically insists on a harmony of wills between the forces of nature (or better perhaps, the Hellenic physical/ cultural environment) and the ruling human powers. It is this conjunction the poet offers as explaining and justifying his opening focus on political felicity. The meaning of the victory is thus first and foremost its meaning for the rulers of Thessaly.

The victory's public, panhellenic character as an advertisement for Thessaly and its regime, no less than for the boy victor, is next recalled in terms that echo the martial note of Herakles' epithet. The people to whom the proclamation was made are a "host," an "army" (stratōi, 8). Given the sixth-century military domination exercised by Thessaly over the Delphian Amphictionic League (Jeffery 1976: 74), the term is by no means politically neutral. At the same time, the military coloring of the term nicely anticipates one of the athletic specialties of the boy's father, racing "in the war-embracing armor of Ares" (13)-a good minor example of overdetermination.

The next major linkages are, given the extraordinary density of Pindar's text, already implicit in the opening lines. Makaira (2) suggests specifically divine blessing; Herakles, son of Zeus, implies the principle of divinely sanctioned transmission of excellence through birth. Thus when the poet's prayer explicitly links the boy's victory with Apollo's intention (10-12) and moves on to insist syntactically (men/de) on the concomitant role of ancestry, the audience has already been prepared for the point:

Apollo, sweet grows both end and beginning for humankind when a god urges it on:

By your devisings, I'm sure, he achieved this

And the Inborn Something stepped in the tracks of his father-

Olympian victor twice in the war-embracing weapons of Ares.

$(10-14)$

The boldly personified abstraction ("the Inborn Something stepped ..., 12) insists that a universal principle is at work. ${ }^{36}$ In the context of the opening (and, as we see below, the end) we cannot confuse this declaration with modern commonsense inferences about a

${ }^{36}$ Gildersleeve $\left(1965: 35^{2}\right)$ prefers to see a less daring construction, taking to sungenes as an accusative of respect, a varatio for a dative of means. Here I agree with Farnell $(1965: 215)$. 
"born" athlete. The success of the victors, father and son, is offered as validation of an entire social and political hierarchy. The continuation of the prayer firmly links this success with an economic hierarchy as well: "May Destiny continue as their companion in later days / As well, so that heroic wealth blossoms for them" $(17-18) \cdot{ }^{37}$ The imagery of natural growth here (anthein) tightens the links. It looks back to the initially weak metaphor of growth (auksetai, 10) in the gnomic declaration of divine involvement in the pattern of success and forward to the ringing finale, which proclaims that the Aleuadai "lift on high the Thessalians' state, / And make it grow [that is, prosper (auksontes)]" (70-71).

The end of the prayer associates the felicity the father and son have won in the games with an extremely abstracted vision of human (Greek) felicity in general: "Of the delights in Hellas / Their allotment is no small gift" (19-20). Burton, writing in the same year and thus without knowledge of Bundy, declares that "there can be little doubt that both ta en Helladi terpma in v. 19 and aglaiais in v. 28 denote in this context athletic glory" (1962: 6). Burton here, like Bundy (1962: 2, quoted earlier), is right to point to Pindar's usage in other poems as a basis for establishing this concrete aspect of much of Pindar's abstract diction. But both are myopic to ignore the fact that it is in this generalizing language, this crucially suggestive shift from the concretely athletic to the generally human (cf. broton ethnos, 28), that Pindar succeeds in insisting on the broader relevance of this particular 40o-meter teenage dash. To insist by this maneuver that a peculiar physical activity, which the structure of economic life in Greece of this period substantially confined to the small class of males who could afford the leisure to train and the luxury of professional trainers, represents the summit of human happiness is supremely ideological. ${ }^{8}{ }^{8}$ As we have already noted, there certainly were those already in the seventh and sixth centuries B.C. who strongly disagreed.

The poet's prayer for the continued felicity of the family shifts smoothly into gnomic meditations on the limitation of human felicity inherent in the distinction between mortal and divine: "may they not

37 The kai ("as well") seems to preclude interpreting the prayer as a wish that a poor or moderate family become rich, an inference one might easily draw from most translations. On the other hand, D. C. Young's emphasis $\left(1985: 115^{-27}\right)$ on the size of the material benef jts resulting from winning could, in the absence of other indications of the established prominence of this victor's family, be used to suggest that future victories alone are the point of the prayer.

${ }^{38}$ Though, as noted, D. C. Young $(1985)$ has effectively challenged the cliche of a total aristocratic monopoly, he has not, I think, succeeded in showing that a majority of the athletes in the early fif th century were likely to come from the small middle class. On the contrary, even he acknowledges that the really poor would be quite unlikely to compete $\left(15^{8-59)}\right.$. 
encounter / Envious reversals from the gods. One heart-free of pain / Would be a god" (20-22). The image of the complete freedom of divinity from suffering functions on the eulogistic level as a foil for launching into a generalized declaration that the situation of the victor's father, who has both won victories himself and lived to see his son's victory, represents the absolute limit of human felicity:

but fair-fated [eudaimōn] and an object of song that man becomes through poets,

Who, after winning victory by the excellence [aretai] of his hands or feet,

Seizes the greatest of prizes through daring and strength,

And-still alive-

Beholds his young son duly meeting with Pythian crowns.

The term eudaimōn (22) recalls daimonos in line 11 and indirectly makaira in line 2; again the victor's felicity is linked with divine favor that extends to the political status of his homeland.

Pindar recapitulates his divine foil and his assertion that Phrikias has achieved the ultimate in human happiness by two images of journeying (ambatos, 27, and eschaton ploon, 28-29) that lead directly into the myth of Perseus' visit to the Hyperboreans:

The bronze sky is never scalable [ambatos] for him:

But as for such delights as we, the mortal race,

grasp, he completes the sea voyage to the ultimate

Point. Neither with ships nor if you went on foot could you find

The marvelous way to the contest of the Hyperboreans.

Beside them once upon a time Perseus, leader of the host,

Feasted, coming on his way home,

Happening upon them as they were performing glorious hundred-strong sacrifices of asses

For the god. Continually in their festivities

And prayers Apollo takes the greatest delight

And laughs when he sees the towering arrogance of the beasts.

The Muse does not leave town

In response to their behavior: everywhere choruses of maidens,

The cries of lyres and the piercing ring of flutes whirl around;

And binding their hair with golden laurel,

they carry on their revel harmoniously.

Neither diseases nor destructive old age is blended

Into that holy race. Without work or warfare 
They dwell, scot-free from

Super-exacting Nemesis. But once upon a time there came Danae's son

Breathing with a daring heart-and Athena lead the way-

To the throng of these blessed men. And he slew

the Gorgon, and the variegated head

Decked with locks that were snakes he came and brought for the islanddwellers

As stony death.

At least since the time of the scholiast, who pronounced this myth a "senseless digression" (alogöi parekbasei, Drachmann 1964 [1903]: 2: 245), there has been considerable debate over its relevance to the eulogistic situation. Does it demonstrate the limitations of human success or suggest the possibility for the victor of at least momentarily transcending those limitations as Perseus did? This is a central issue to which we must return, but an impressive range of scholars, culminating in Köhnken, have argued, to use Gildersleeve's words, that "the land of the Hyperboreans is a glorified Thessaly" and Perseus is an heroic paradigm for the achievement of the victors. ${ }^{39}$

A rich array of verbal echoes and images imply these parallels. The word Pindar uses to suggest the "gathering" (agōna, 30) also means "contest" and recalls the agōn (16) that rendered Phrikias victorious. Perseus shares in a banquet (edaisato, 31 ) including a sacrifice (33-34). The lifestyle of the Hyperboreans is characterized by choral poetry, lyres, and flutes (37-39). The banqueters bind their hair with garlands as they make merry (40). Of these details, only the choral song $(6,53$, $55^{-57}, 65$ ) is specified in text, but it is a reasonable inference that each has an analogue in the setting and occasion of Pindar's ode. The $\mathrm{Hy}-$ perboreans are a "holy race" (42), and the occasion of the ode inspires Pindar to pronounce Thessaly "divinely blessed" (makaira, 2). Perseus is a "leader of the people (or host)" (lagetas, 31), despite the fact that all salient features of his myth deal with individual actions. As a rough equivalent of "heroic king," the term echoes the explicit political focus of the opening and anticipates that of the ending. Apollo, the god at whose games the victory occurred and to whom it is in part attributed (10-11), is prominently featured in the myth as the crowning element in Hyperborean felicity $(34-36)$. Perseus comes "breathing with a

${ }^{39}$ Gildersleeve 1965: 350, J. H. Finley 1955: 28, van Groningen 1958: 350, Burton 1962: 8, D. C. Young 1971: 35, and Köhnken 1971:158-87. Of all the authors who have noted various parallels between the eulogistic context and the myth, Köhnken is by far the most detailed. By comparison, I offer only a discrete little sampling of the possible evidence without further acknowledgment. 
daring heart" (44); the victor "seizes the greatest prizes through daring and strength" (24). Perseus is the son of Danae, and Athena leads him (45); the victor trod in his father's footsteps and won by Apollo's devices (11-12). Finally, lest the audience fail to get the point of their divinely endorsed privilege, Pindar sums up Perseus' visit as coming to a "throng of . . . blessed [makarōn] men" (46), having earlier, as we noted, declared the victor's homeland "blessed" (makaira, 2).

Just as the required gnomic element lifts the specific athletic victory into an abstracted, universalizing vision of general human felicity, so the anticipated myth functions on one level to exalt the victory into the category of permanent cultural exemplars. ${ }^{4^{\circ}}$ The implication is thus present that today's ruling class are worthy successors to the paradigmatic figures of the past, an idea already adumbrated in the initial allusion to ancestry traced from Herakles. The past to this extent validates the status quo. The emphasis on the justice of the Hyperboreans (44) looks forward to the explicit praise of the Thessalian regime as characterized by "an upright mind" $(67-68)$. So the presence of the Muse among the Hyperboreans facilitates the association of the ruler's solicitude for the poet $(64-66)$ with the uprightness of the entire regime, which itself is offered gnomically in the final lines as representative of the general superiority of inherited aristocratic political regimes:

I have confidence in the kindly hospitality of Thorax, who in solicitousness for my favor,

Yoked this four-horse chariot of the Pierians [Muses],

Loving one who loves him, leading one who leads eagerly.

On the testing touchstone gold shines forth

And the upright mind.

And we shall praise too the noble [eslois] brothers, because they lift

On high the Thessalians' state [nomon],

And make it grow [auksontes]. In the hands of the good [en agathoisi] rests

The careful steering of cities, handed down from father to sons [patrōiai].

$(64-72)$

The preceding points in my negative hermeneutic are all elements which in principle Norwood or Moses Finley might cite in an indictment of Pindar the "toady," Pindar the "muddle-headed reactionary." The raw material, so to speak, of this demonstration is also what proponents of the purely panegyric approach might cite in defense of Pin-

\footnotetext{
$4^{\circ}$ For omission of myth or substitution of a compensating element in the structure, see Hamilton 1974: 39 and D. C. Young 1971: 34 .
} 
dar's fundamentally coherent and artistically adroit praise of the victor-minus, of course, the irksome intrusion of such notions as politics, class, and ideology. Although my own approach eschews a precipitous rush to judgment, I do maintain that none of these elements is truly extraneous to the text of the poem, and a definition of poetry that can give no account of them is, for me at least, inadequate.

\section{The Positive Hermeneutic}

In turning to a positive hermeneutic of Pythian 10, I should perhaps disabuse the reader at the outset: I do not succeed by some dazzling critical or rhetorical sleight of hand in transforming Pindar into a crypto-revolutionary. What is at stake, I must repeat, is the spontaneous acceptance of the ruling-class version of reality as the only reality. The nearest thing to a subversive activity I attribute to Pindar is the self-consciousness of his affirmation that he alone as poet controls access to that realm of full gratification which might otherwise appear as the automatic consequence of inherited wealth, political power, and athletic success. Moreover, what is most shocking in Jameson's theorization of the double hermeneutic is that fundamental aspects of what is negative are simultaneously positive. Most centrally, the utopian image of the ruling elite as a perfect community-the most obviously "toadying" aspect of the poem-is, from the perspective of the long struggle for human freedom, the dimension that most distances the poem from the actual status quo and offers us a realm of freedom to appropriate and extend well beyond its putatively intended ideological function.

But before looking more closely at the obviously self-conscious aspects of Pindar's posture toward his audience or reconsidering its most clearly utopian dimensions, it is essential to consider all the less conscious elements in his epinician, which, by virtue of their formal effectiveness, distance it from that spontaneous reflection of rulingclass reality so readily attributed to it by Pindar's politically minded detractors.

Though we have no direct access to the language by which the rulers of Thessaly or the rest of Greece constituted their version of reality, we may plausibly surmise that it was not Pindar's language. Obvious and not so obvious aspects of Pindar's language dramatically distance it from any imaginable spoken language and mark it as a vehicle for the constitution of a different sort of reality. We have already noted that Pindar's formal metrical patterns represent one of the most striking factors (perhaps more significant even than the irretrievably lost music and dance patterns) differentiating his language from the everyday 
language of the ruling class. ${ }^{41}$ Pythian 10 , like thirty-eight of his extant forty-four epinicians, is arranged in elaborate triads, with metrically matching strophe and antistrophe, answered by an epode that recalls but does not repeat their metrical form. As noted earlier, Pindar combines various traditional metrical cadences so unpredictably that no extant complete poem has precisely the same structure. Metrically, then, the poem is simultaneously both monumentally ordered and disorientingly free. In Pythian 1o, the so-called choriambic nucleus (long/short/ short/long) of traditional Aeolic meters recurs once or twice in every line of both strophe and epode, but the amplifications before and after the nucleus are different in every line in such a way that sometimes, we imagine, it may evoke traditional folksong Aeolics, and other times it may seem to shift into a dactylic cadence.

In the handling of the triadic pattern there are in this presumed earliest poem recognizable pauses in sense between triads. Yet parallel optatives hepoito (17) and epikursaien (21) imply that we are meant to understand the prayer begun at line 10 continuing into the second triad and ending at line 21. Though we do not find in Pythian 10 the really extraordinary enjambments that characterize some of Pindar's greatest poems (Mullen 1982: 93-98), certainly "Olympian victor" (13), "Muse" (37), "The gods bringing to fulfillment" (theōn telesantōn, 49), and "testing" (peironti, 67) clearly gain in emphasis from their position as the initial words of epodes, strophes, or antistrophes. The tension created and played with between the repeating triadic structure and the linear movement of laudatory argument is a further distancing factor that sets the poet in a position of control and sets the audience in a posture of tantalized dependence.

Pindar's diction, syntax, imagery, and mastery of rhetorical tropes render his language easily the most complex and demanding in Greek literature. Given the extent of our losses, we can never be sure that a word occurring for the first time or only in Pindar is a true neologism, but the list of words which seem to fit this description in so early a poem is striking. Some are new compounds built on a clear Homeric model: "best in battle" (aristomachou, 3), "foot-victorious" (kratēsipoda, 16), "host/people-leader" (lagetas, 31); some are poetic abstractions, pointing the path to the diction of the Sophists: "turnings-after" (sc. reversals) (metatropiais, 21 ), "fair-speakings" (euphamias, 35), "steerings" or "pilotage" (kubernasies, 72), to which should be added the poetic abstraction formed by the article with the neuter adjective, to sungenes

${ }^{41}$ This comment in no way disparages the fascinating explorations by Mullen of the dialectic of dance pattern and meaning. Mullen himself $(1982: 43-45)$ has given the best explanation of why there is no dance notation; his most perceptive insights presuppose the dominance of the still very observable metrical pattern (see his chap. 3, "The Triad"). 
(12). ${ }^{42}$ Some of these neologisms seem merely simple realizations of linguistic potentialities of ordinary Greek: "singable" or "song-worthy" (hymnētos, 22), "super-just" or "super-exacting" (hyperdikon, 44), "without offering evidence" or "obscure" (atekmarton, 63). But these potentialities were apparently unrealized by earlier authors. The verb "leave town" (apodamei, 37) appears an almost coy, playful coinage in conjunction with litotes.

Some dozen particularly Homeric words and expressions add a distinctly epic flavor to the language of Pythian 10, but Pindar does more than evoke a general aura of the epics. ${ }^{43} \mathrm{~A}$ phrase such as "breathing with a daring heart" (thraseiai pneōn kardiai, 44) points in the direction of his characteristic allusive posture toward epic formula: it recalls the Homeric formula "breathing might" (menea pneontes), which always occurs in the nominative plural. The word apémon in line 23 occurs only once in the nominative in Homer (in Thetis's poignantly futile wish that Achilles might "sit by the ship free of tears and free of suffering," $\mathrm{Il}$. $1.4^{1} 5^{-16)}$. For an audience brought up on Homer, it is not too much to suggest that the word carried connotations of the paradigmatic Greek embodiment of mortal limitation. The word kanakhai is used in Homer of clashing weapons, the ominous tramping of an army's feet, the gnashing of teeth. Pindar's use of it to evoke the sound of flutes in a joyful celebration transforms its menacing connotations. His use of the Homeric agēnor (Doric aganor, lit. "very manly"), usually the attribute of bold or excessively confident heroes, to describe the exceptional wealth of the victor's family lends a note of moral ambiguity that nicely anticipates the subsequent reference to envious reversals from the gods (Méautis 1962: 37).

One must resist the temptation to try to spell out all the subtleties of Pindar's language, a favorite occupation of the belles-lettrist school.44 These few examples must suffice. The net effect of Pindar's language is surely a dazzling display of the poet's unique power over the medium

\footnotetext{
${ }^{42}$ See $L S J$ s.v. IIc, where Pythian 10 is the earliest instance of a coinage that apparently appealed to Aeschylus, Sophokles, and Thucydides. Snell (196o: 22 7-28) ably comments on the great convenience for the development of scientific thought of abstractions made from the article with a verb or adjective. The point was first brought vividly home to me in lectures by E. A. Havelock, but a perusal of his published corpus has not yielded precisely the point I seek.

${ }^{43}$ E.g., "glorious" (klutan, 6); "manly" (aganora, 18); "free from pain" (apèmon, 22); "brazen sky" (khalkeos ouranos, 27); "scalable" (ambatos, 27); "accomplishing glorious hecatombs" (kleitas hekatombas ... rhezontas, 33); "beasts" (knōdalōn, 36); "clashings" (kanakhai, 39); "destroying" (oulomenon, 41); "came" (molen, 45); "slew" (epephnen, 46); "floss"/ "flower" (but see Raman 1975) (aōtos, 53); "eagerly grasped" (harpaleon, 62); "bustling about" (poipnuōn, 64).

${ }^{44}$ For a particularly fine recent demonstration of Pindar qua jeweler of language at the level of stylistic devices, see Race 1989 .
} 
that most fully constitutes human reality. He can create new collocations, evoke and transform the authoritative world of Homer, extend the potentialities of ordinary syntax so that his language, like his meter, tantalizes with its simultaneous display of freedom and extraordinary control. The power of this language is the real validation of Pindar's claim to bestow something unique on the victor and his class. The gratification it offers is simultaneously an overwhelming negation of the discourse controlled by the ordinary members of the ruling class. Pindar can justifiably imply that he alone as poet lifts the victor, his homeland, his family, and his class out of the limitations of their reality into a fuller state of being: "Fortunate [eudaimōn] and celebrated in song [hymnētos] that man becomes [ginetai] sophois" (22-23). How are we to understand this dative sophois? Most translators and commentators either separate it from eudaimon and take it as dative of agent with hymnētos (e.g., Puech, "Heureux et digne d'être chanté par les poètes" 1970 [1922]: 2:147) or respect the word order and take the dative as a weak dative of interest (e.g., Gildersleeve, "is accounted in the eyes of the wise" 1965 [189o]: 353 , or Farnell, following the scholia, "becomes in the opinion of the wise," 1965 [1932]: 217). But Burton rightly sees in the phrase "a further hint of the necessary connection between victory and song" (1962: 6). ${ }^{45}$ The actual construction boldly implies that the man's achievement of true blessedness depends on his being celebrated in song by skilled poets.

Bundy and his disciples have been at pains to stress that the persona of the poet (what Hamilton designates "the Poet's Task") in the epinician is entirely subordinated to conventional strategies of praise such as insisting on the sincerity of the laudator, the bond of true friendship between the laudator and laudandus, abjuring exaggeration, of fering reassurance about the long-term efficacy of the praise, and so forth (Bundy 1962: esp. 3, 40). But even granting the general legitimacy of this approach, I am still struck by the relative prominence and boldness of Pindar's self-presentation in comparison with our only basis for comparison, Bacchylides. To be sure, there is less of Bacchylides, and many of the epinicia we have are fragmentary. But in none of the reasonably complete poems is there anything comparable to the proportionate focus on poetry and the poet even in Pythian 10, which is by no means Pindar's most self-reflexive poem. In addition to four first person verbs $(4,55,64,69[\mathrm{pl}]$.$) , two emphatic first-person pronouns (4,$

${ }^{45}$ For some parallel translations, see Bowra, "that man is happy and poets sing of him" (1969: 22); Lattimore, "blessed, worthy the poet's song, is that man" (1947a: 87); Nisetich, "worthy of song" (1980: 216). Farnell adds to his preferred rendering a second possibility, "the dative may go directly with hymnetos, 'besung by the craftsmen of song'" (1965: 217 ). The scholia reads para tois sophois ginetai (Drachmann 1964: 2: 244). 
48 ), and an emphatic first-person possessive adjective (56), we find about thirteen lines out of seventy-two with a primary focus on the poet, poetry, or music $(6,22,37-39,51-57,65){ }^{46}$ Although two Bacchylides fragments (14 and 26 Snell) speak of sophia in terms that may imply poetry, sophos is used in his epinicia apropos of a skilled athletic trainer (13.201), in a priamel (Bundy 1962: 4-5) describing various sorts of human epistemai (10.39), and in a simile comparing himself to a skilled helmsman (12.1). In this last case most obviously, but in the other two probably, we may suspect a coy self-reference. But nowhere in Bacchylides is there the blatancy with which Pindar uses sophoi, just as Xenophanes uses sophia, here and in later poems to arrogate to poets all skill and wisdom absolutely.

This simultaneous display of and insistence on poetic power is not politically neutral. Like the poet of the Odyssey, Pindar consciously distances himself from his audience in proclaiming the specialness of his powers as a poet. This distancing is not so much bridged as underscored by the numerous metaphors scattered through his poems which imply a parallel between Pindar's poetic struggles and those of athletic competitors. Pindar's prowess is in the sphere where his patrons must be presumed most inferior to him. In Pythian 10 Pindar celebrates a relatively modest victory in a boys' footrace, but for his own poetic act he chooses as metaphor by far the most prestigious of all contests, the four-horse chariot race $\left(6_{5}\right)$.

To be sure, Phoinix in the Iliad ranks speaking along with deeds of war in the making of a hero (9.443). But even the extremely articulate Odysseus resorts to brute force when meeting a verbal challenge from someone outside the ruling elite (Il. 2.265-66). Pindar's consciousness about the power of speech is (regardless of his class loyalties) inextricably bound up with concurrent intellectual and political developments inimical to the interests of the old aristocratic regimes. Pindar in 498 B.C. is composing some ten years after the emergence of democracy in Athens, a development sufficiently threatening to tempt the concerted oligarchic powers of Sparta, Euboea, and Boeotia (Pindar's homeland) to seek to crush it militarily (Herodotus $5 \cdot 74-78$ ). Pindar was a contemporary or near contemporary of Simonides, Herakleitos, Xenophanes, and Pythagoras-all figures who in varying ways valorized critical, articulate thought to an extent that spelled the end of any spontaneous ideological hegemony exercised directly by the old ruling class. Not only is Norwood's characterization of Pindar as

\footnotetext{
${ }^{46} \mathrm{Me}$ in 4 , though syntactically in the unemphatic second position of its own sentence, gains emphasis by answering the first-person rhetorical question preceding it. Emoi in 48 is emphatic both by position and form. Cf. Bacchylides 3.57 (Snell) for the same sentiment without the personal reference.
} 
philosophically ignorant and intellectually obtuse inherently improbable, it ignores the extent to which the very function of traveling poets and intellectuals made them the cutting edge of ideological struggle. Regardless of the help they may have extended to the ruling element, the relative autonomy inherent in their superior mastery of verbal communication and their role in the growing self-consciousness-in an age of spreading literacy-about the constitutive role of speech in the perception and presentation of reality rendered them a progressive force. ${ }^{47}$ That they could help the ruling class was the most dramatic proof that the ruling class needed help.

If then the conventional focus on the poet's task emerges in Pindar as a two-edged weapon, concomitant with the exalting and distancing function of his language and meter, so too the required gnomic element lifts the power and felicity of the ruling-class figures into a universalized context which at the same time defines their limitations. It is not accidental in Pythian 10 that the affirmation of the poet's power is so intimately linked with the evocation of divine arbitrariness: the ruler's / victors' felicity is a gift of the gods, but the gods may take it away (19-21). Though the explicit phthonos motif invoked in Pythian 10 is relatively rare in Pindar, the opposition between the insecurity of the future and the confident assertion of the poet's power to memorialize the present moment of felicity is a central feature of virtually all the epinicians. ${ }^{8}$ In Pythian 10, the potentially ominous allusions to "Fate" (moira, 17), to the possibility of envious reversals from the gods, and the reminder of suffering as endemic to the human condition (17-22) constitute a distinctly threatening foil to the bold linkage of human blessedness with celebration by poets $(22-26)$ discussed above. The subsequent gnomic statements insist in turn that this felicity, the plenitude of which is so dependent on the poet, is the ne plus ultra of pleasure accessible to the human species (broton ethnos, 28):

The bronze sky is never scalable for him:

But as for such delights as we, the mortal race,

grasp, he completes the sea voyage to the ultimate

Point. Neither with ships nor if you went on foot could you find

The marvelous way to the contest of the Hyperboreans.

\footnotetext{
${ }^{47}$ For detailed discussion of the Presocratics, see $H G P$ vols. 1 and 2. See also Havelock 1982: 220-6o. That Pindar must be seen as a precursor of the Sophists is rightly stressed in Lefkowitz 1976a: 172; see also Farenga 1977.

${ }^{48}$ Farnell $\left(196_{5}: 471-72\right)$ is at pains to dismiss it as a façon de parler, but Burton (1962: 5) rightly recognizes it here as a more blatant form of a recurrent Pindaric topos.
} 
Thus the most categorical statements of the felicity of the victor and his father are sandwiched between two equally categorical generalizations that insist on human limitations. Both syntactically point to their special relevance for the addressees of the poem (autöi, 27; heurois, 29).

To return to the myth, this expected if not obligatory element in the conventional epinician involves by its very nature an ambiguous transcendence of the ruling-class vision of reality. I have suggested several ways that the myth's parallel to the circumstances of the victory and the victory celebration constitutes an intensely partisan effort to validate the social, political, and economic status of the victor, his father, and their supremely powerful friends, the Aleuadai. But the scholarly debate over whether the myth stresses the godlike felicity of the laudandi or constitutes a demonstration of the mortal limitations of that felicity is naive only to the extent that participants seek to impose a univocal message on the text-either a simple exemplar or a simple sermon. ${ }^{49}$ The rich suggestiveness of analogical thought is inevitably bought at the price of a high level of inherent ambiguity (Lloyd 1987 [1966]: esp. $385^{-87}$; D. Steiner 1986:12). Here, in his earliest extant poem, Pindar is already extremely aware of the "hidden rocks" threatening too full an exploration of his mythic analogy (cf. $5^{1-52}$ ). His metaphor of the flitting bee invokes a poetic goal of touching only the relevant details (53-54), but no speaker using an analogy can escape the fact that whatever is illuminatingly similar sheds that illumination by virtue of being significantly different. Moreover, we have already noted that the form in which Pindar chooses to introduce his mythic analogy conf ronts his audience first with a difference posited as both absolute and of fundamental importance. The inaccessibility of divine felicity is the point of departure for a myth containing so many hints of godlike felicity achieved by the victor and his company.

Perhaps the most fundamental noncorrespondence of the world of the Hyperboreans to Thessaly is the temporary nature of the latter. The divine participation of Apollo in the Thessalian felicity is only a supposition ("I'm sure" or "I suppose," pou, 11) in regard to a single achievement; but among the Hyperboreans, Apollo's pleasure is "permanent," "fixed" (empedon, 34). Within the myth, the temporary character of the human hero's participation is twice stressed ("once upon a. time," or simply "once," pote, 31,45 ). In the poet's praise of the victors, the stress on the precarious, temporary nature of their felicity is, as we

\footnotetext{
${ }^{49}$ Among those insisting on the sermon approach (even after Köhnken's mighty assault) must be numbered Radt, who in his review of Köhnken singles out this point on which to chastise him (1974: 119).
} 
have seen, the point of departure for the myth. It recurs emphatically in the gnomic elements following the myth:

Of the things each man drives after,

Let a man, if he wins it, keep it a dear thought beside his foot;

But what will come a year from now there is no clue to foresee.

$(61-64)$

Even the detail of the golden garland suggests not only the transcendentally superior wealth of divine felicity but immortality in contrast to the ephemeral foliage of human banquet garlands or victory wreaths $\left(26,5^{8}\right.$, and J. H. Finley 1955: 53-54). Similarly, the litotes of ouk apodamei ("does not leave town," 37) followed by pantai ("on every side," 38 ) suggests that poetry is a pervasive and permanent feature of the Hyperborean mode of life.

The explicit catalogue of human ills from which the Hyperboreans are free (disease, aging, work, warfare, and "super-exacting Nemesis," 41-44) is the chief barrier in the text for those who wish to emphasize only the parallels. In the nonmythic portion of the poem, we have noted the apparently unqualified validation of the reliance of the Thessalian regime on military domination. To present freedom from battles as characteristic of absolute happiness does constitute a qualification, a partial negation of this aspect of the political order. Human aging too is indirectly alluded to in the praise of the victor's father for living to see his young son's success: the collocation "living [subject] still young [object]" (zōōn eti nearon, 25) is not without a touch of pathos. The climactic placing of Nemesis, further emphasized by the apparent neologism hyperdikon (44), cannot be explained away as simply a periphrasis for death, in which case it emerges as only a weak gloss on the freedom from aging..$^{50}$ It is much more appropriate, I think, to see in it an echo of the "envious reversals from the gods" (22-23). The envy of the gods is directed precisely at extreme human felicity, which they tend to punish with a reversal of fortune. To offer an image of supreme felicity that specifically escapes this danger is thus a further implicit negation and transcendence of the illusory and relatively precarious status of the rulers of Thessaly. If we say that the nonmetaphysical implications of phthonos and nemesis are envy and resentment not from the gods above but from human rivals lower on the social and political hierarchy, the relevance of the motif is more ideologically pointed.

To this extent, then, the myth projects a genuinely utopian vision; it embodies that transcendent negating "promesse de bonheur," which

${ }^{5 \circ} \mathrm{Cf}$. Köhnken 1971: 163-65-another argument challenged by Radt (1974: 119). Köhnken cites, but essentially ignores, those who relate Nemesis to phthonos (163). 
Stendhal, echoed by the Frankfurt School, attributed to all true art (Jay 1973: 179). Its laudatory function by no means exhausts its meaning, for it explicitly evokes a realm of freedom available neither to the rulers of Thessaly nor to their subjects.

Two aspects of the myth have especially troubled commentators concerned with exploring its relevance to Thessaly and the victors. One is the laughter of Apollo at the donkeys about to be sacrificed and, more specifically, the meaning of hubrin orthian (36). The second is the powerful sketch of the kernel of the Perseus myth, the slaying of the Gorgon, the revenge exacted by turning Polydectes and his followers on Seriphos to stone. Most readers have taken hubrin orthian to mean that the donkey have erections. Bowra in his translation neatly combines this sense with the more general moral connotations of hubris: Apollo "laughs as he sees / Their beasts' high-cocked presumption!" (1969: 22). On this view, Apollo's amusement at their proverbial lasciviousness reflects his capacity as god of restraint; he laughs morally because they will soon be punished..$^{1}$ Köhnken, presumably not out of the "prudery of schoolroom philology" mocked by Wilamowitz-Moellendorff ( 1966 [1922]: $127 \mathrm{n} .3$ ), has recently launched a heavy barrage at the erection construction. Reviving an argument at least as old as Mezger (1880: 258), he cites other instances of orthios in Pindar that refer to pitch and cites passages in other authors complaining of the harshness of braying. He then argues that this passage in Pythian 10 is a pointed foil to the following focus on poetry. Apollo, the god of harmony, laughs at the imminent punishment of the donkeys' disharmony (Köhnken 1971: 161-62).$^{2}$ Both views attribute a somewhat sinister moral force to Apollo's laughter: he enjoys the prospect of repressing their "evil" by death.

The first part of the passage on Perseus is relatively easy, as we have seen, to integrate with praise of the victor's boldness, aristocratic descent, and divine favor. But is the hauntingly powerful sequel mere background, a sort of poetic footnote to Perseus' visit to the Hyperboreans (cf. Burton 1962: 9; Wilamowitz-Moellendorff 1966: 126)? Certainly the intensity of horror and the immediacy of death it evokes mark one of the sharpest nonparallels to the competition of young boys on the race track. It is possible to dismiss the problem by simply stressing that mythic paradigms in Pindar are inherently partial or by pointing to the playful hyperboles in the fragments of Simonides'

${ }^{51}$ Van Groningen (1958: $35^{\circ} \mathrm{n} .3$ ) cites and rightly rejects the view of earlier scholars that the reference reflects the poet's light-hearted chiding of his hosts' lascivious comportment. He states flatly, however, his own despair of making any sense of the passage.

${ }^{52}$ Like Gildersleeve (1965: 354), I do not find "as he sees" (horōn, $\left.3^{6}\right)$ as easy to dismiss as Mezger and Köhnken seem to. 
epinicia. I prefer to see the two passages as related to each other and integrated into the various dualities I have been pointing to in the poem. Just as Apollo's laughter of fers an image of the simultaneous enjoyment and cheerful suppression of raw, animal sexuality to be sublimated as poetry and song, so the kernel of the Perseus myth evokes the darker joy of the hero's violent and murderous suppression of female and male sexual threats. ${ }^{53}$ These two passages, read in conjunction, mark in Pindar's vision of an ampler realm of being the projection of intense censorship against the very erotic energy that itself engenders the utopian impulse.

But what is censored even in utopia is within the poet's power to bestow in the real world of the athletic encomium. The songs of the poet invest the victor with enhanced sexual attractiveness to both men and women:

I hope that, as the Ephyraians

Are pouring forth my sweet voice round about the Peneios [Thessalian river],

I shall make Hippokleas even yet more admirable

With my songs for his crowns in the eyes both of

his age mates and too of those who are older,

And make him a source of love-pain to maidens. For it is true

That passions for different people chaff different minds.

Some commentators have been troubled by the explicitness of this gnomic statement, which seems to subsume all human wishes as various forms of erotic desire ${ }^{54}$ But that vision, as we have seen, is already implicit in the myth. The poet, like god and hero, can repress, sublimate, or inspire and fulfill desire.

\section{History and the "Inner Logic of the Poem"}

In the preceding application of a double hermeneutic, I have tried to respect the text of the poem and its formal dimensions, to permit, in Jameson's words, its "inner logic . . to dictate the specific terms of its own interpretation" (1971: 333). The inner logic of Pythian 10 leads both to the fervent realization of aristocratic ideology in image, structure, argument, and to the transcendent negation of that ideology in its

\footnotetext{
${ }^{53}$ Here I am indebted to Philip Slater's brilliant and much-maligned work on Greek myth (1968: esp. 308-33).

54E.g., Burton 1962: 11, Farnell 1965: 219-20, and van Groningen 1958: 347-48.
} 
celebration and demonstration of the poet's mastery of access to a realm of being free of pain and guilt, full of sensuous gratification, and quite beyond the limited reality of the Greek ruling class. Indeed, it is in the end a moot point whether the net effect of the poem is more a celebration of their power or his.

Historicizing in this sense includes a full acknowledgement of the poet's ideological function without reducing his poetry simply to a partisan political message. The pleasure that Pindar's poetry offers is neither apolitical nor a sort of seductive honey smeared on the cup rim to hide the bitter wormwood within. The pleasure of form both contributes to the effectiveness of the ideology and calls attention to its limitations by evoking a realm of gratification that transcends the power of those who rule the poet's world.

It would thus be false to conclude that only the elements of the positive hermeneutic have positive aesthetic interest and value. "Negative" and "positive" are not in this sense essentialist value terms. Although they imply taking a stand historically, because history continually changes the rules of the game, they do not define or conf ine the meaning or value of Pindar's poetry exclusively to its role in its own historical moment. There are in fact aspects of our contemporary ideological conflicts which render Pindar's poetic triumph as pure eulogist particularly appealing to those willing to read him. Late monopoly capitalism, especially in its phases of chronic crisis, frantically seeks to prevent us from making meaningful mental connections. It barrages us ceaselessly with a relentless compartmentalization, a radical fragmentation of every dimension of our social being (Lukács 1968: esp. 27). Private life is represented as radically distinct from public life, politics from economics, consumption from production, spiritual life from material life, and so on. In academia this is reproduced in heavily ideological efforts to sharpen and maintain strict boundaries between department, disciplines, and "terrains." Something very immediate in us, then, responds to the deeply integrative imagination of Pindar, who in contrast can articulate a vision in which the macropolitics of Greece, a specific athletic victory, divine governance, the force of heredity, the mythic past, heroic exemplars, and the intimate world of a teenage boy's sexual interest can all be harmoniously integrated with the diversity of human desires, the fragility of success, the warmth of a specific host, the world implications of poetry, and the ideal form of political constitution. The "linear argument" of the eulogistic function is in fact a point (J. H. Finley 1955: 6-8) where for a beautiful moment all the potential fragments of existence coalesce and sing. We need not adopt the content of the vision to be aesthetically enriched by the demonstration that such integration is possible. 
That beyond this achievement Pindar also succeeds in exhausting and transcending the ideology of his class in a utopian affirmation of a higher order of being does enhance the aesthetic richness of his art. Pythian 10 is not the easiest of ancient texts to which one might apply this dialectical hermeneutic. Yet few literatures are as blatantly concerned with and implicated in the class conflicts of their societies as Greek and Latin literature. At the same time, few literatures display so self-consciously a belief in the relative autonomy of the artist. There is no pretense that a Sappho, a Solon, a Xenophanes, or a Pindar is not politically engaged; yet each, as a poet, sits in judgment on his or her society and evokes through artistic means a vision of a more profoundly gratifying world. 